\title{
MEMORY STIDIES
}

\section{Mapping and excavating spectral traces in post-apartheid Cape Town}

\author{
JULIAN JONKER, University of Cape Town, South Africa \\ KAREN E. TILL, Virginia Polytechnic University, USA
}

\begin{abstract}
This article explores how spectral traces at places marked by acts of violence and injustice allow residents to come into contact with past and future inhabitants of the postcolonial city. We examine controversies surrounding Prestwich Place, Cape Town, an informal burial ground for colonial underclasses that was unearthed when construction began for an upscale 'New York-style' apartment and office complex. The human remains that emerged embodied a past that exceeded national narrations of public memory and presented this past as an object of concern for private capital and activists. Rather than offer a biography of the site, we develop two concepts, memorial cartographies and haunted archaeologies, that represent terrains not visible on Cartesian mappings. We understand these narrative strategies as creative acts that honour those who have gone before; both practices encourage us to listen as witnesses to geographies of loss that continue to structure contemporary urbanisms.
\end{abstract}

\section{Key words}

District Six; haunted archaeologies; memorial cartographies; post-apartheid Cape Town; postcolonial cities; Prestwich Place; spectral traces

We kept candlelit vigils there [at Prestwich Place], letting the bones know we were there, that we were present, we were with them. As we stood, with the wind coming down from the mountain, the candles flickering, it was as though the bones were speaking to us.

And what did the bones say?

That they should not be forgotten again. They acknowledged our presence, grateful that we were with them. (Stan Abrahams, citizen activist and founding member and Trustee of the District Six Museum, interview with K. Till, Cape Town, 2005) 
How do bones speak? This is a question raised by the rhetorics and practices centring on Prestwich Place, a slave burial ground in Cape Town, South Africa. Prestwich Place was simply one of many construction sites in the heart of a city in transition, until the skeletal remains of more than 2500 slaves and members of the colonial lower classes were unearthed by unsuspecting construction workers in June 2003 (Grunebaum, 2007; Ralphs, 2008; Shepherd, 2007; Weeder, 2006). . ${ }^{1}$ The 2800 sq. m plot, located in the chic and highly desirable inner city precinct called Green Point, was once part of a much larger set of 17th- and 18th-century informal burial grounds. A large portion of the district, a $1 \mathrm{~km}$ by $1.5 \mathrm{~km}$ area, is affected by this discovery, since burials are known to extend far beyond this particular plot (Cape Argus, 2008; Gosling, 2003; Vasta, 2003).

At the time of the unearthing, property in the precinct was considered the highest priced real estate in the country (Cape Times, 2003; Moodie, 2004; Thiel, 2004). Yet, capital's vision of a future built on gentrification was interrupted by the dead, aided by their living mourners. Activists claiming descendancy from those buried at Prestwich Place momentarily halted development by protesting heritage authorities' failure to provide an adequate public consultation process. In addition to appealing against the authorities' insistence that the remains be exhumed, activists demanded that the site be memorialized; they kept candlelit vigils by the excavations to 'keep the bones company' (Figure 1) (Abrahams, interview with K. Till, 2005; see also Hands Off Prestwich Street Ad Hoc Campaign, n.d.; Kassiem, 2003; Prestwich Place Project Committee, 2004; Weeder, 2003).

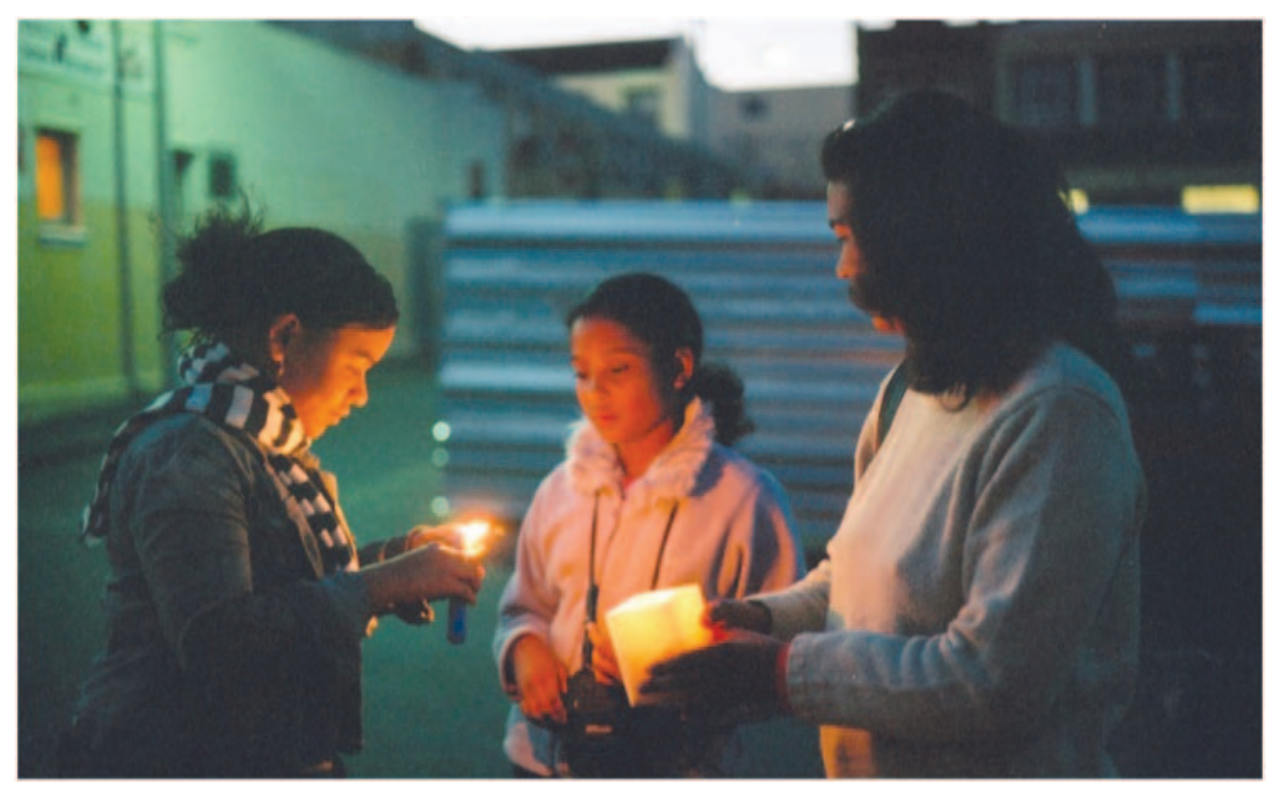

FIGURE 1 Candlelight vigil at Prestwich Place, 2003

Image courtesy of the District Six Museum photographic collection. 
Competing claims to Prestwich, by developers, national heritage authorities, city planners, activists and residents, raised questions about the priority of property rights and urban renewal over ancestral burial site. These debates soon evolved into disputes about what should count as national heritage, and about whose knowledge and interpretation of human remains should be privileged when evaluating claims to descendancy and belonging. Ultimately the debate came to be framed as one that pitted the epistemological and ethical claims of public memory and archaeology against one another (Shepherd and Ernsten, 2007: 222-5). Commentators asked: '[a]re the bones of the Prestwich Street dead artefacts? Or are they ancestors?' (Shepherd, 2007: 19).

But the spectral traces of Cape Town's urban slave heritage did more than challenge visions of an urban future built on private investment and public-private partnerships, or unsettle fantasies that disciplines could be purged of their historical debts. They also emerged as if to haunt the memorial foundations of the new nation. For while much effort in building a post-apartheid South Africa has focused on memorializing loss, rewriting historical narratives, transforming public memory and claiming a distinctive ancient African heritage (Coombes, 2003; Nuttall and Coetzee, 1998; Rassool et al., 2002), these 'usable pasts' (Cohn, 1983) and claims to African heritage have continued to marginalize Cape Town's violent inheritances of slavery and colonialism.

Relative to the emerging South African narrative, the city of Cape Town and the Western Cape region have distinct political and social histories; social relations in the region are characterized by regionally specific and persistent legacies of indigenous genocide, colonialism, slavery, racial segregation and displacement, apartheid, and postapartheid racial and social tensions. This has meant, for example, that many residents of the city continue to use the apartheid racial identity of 'coloured', despite the fact that cultural formations in the city have roots in the rich diversity of cultures and creolizations forged by the slave trade and the city's position on 19th-century trade routes (Erasmus, 2001a; but see Soudien, 2008: 21-22). Yet this discourse of coloured identity has often worked to silence narratives of slave ancestry. Lingering myths of racial purity and impurity have, in this way, been reinforced after apartheid, and those who have neither 'purely African' nor 'purely European' ancestries remain characterized as having a lesser claim to belonging in the new nation (Adhikari, 2005).

Even the progressive work of transformation and constitutional transition, initiated by legal reforms of the early 1990s and exemplified by the Truth and Reconciliation Commission (TRC), formulated a historical narrative of the nation that often neglected certain dimensions of Cape Town's complex past. Spectres of this colonial history therefore continue to haunt both the contemporary city and the imagination of transition, as transformational and memorial strategies fail to exorcise pre-apartheid injustices, in particular the consequences of slavery at the Cape and its distinctive discourses of racial impurity. The human remains that emerged at Prestwich Place thus embodied a past that exceeded national narrations of public memory, and also presented this past as an object of urgent concern for private capital and activists alike.

In this article, we explore how spectral traces, especially at places marked constitutively by acts of violence and injustice, allow contemporary residents to come into contact with past and future inhabitants of the city. If the city is theorized as a palimpsest 
(Bender, 1998; Huyssen, 2003; Schein, 1997; Shepherd and Ernsten, 2007; but see Massey, 2005: 110), the surfacing of the dead is a moment of irruption of what has sunk from sight. The very aptness of the notion of the palimpsest, that archaeological metaphor that would transpose time onto depth (as if both were linear), is rendered inadequate by such an intrusion. As Grunebaum describes, '[o]n the fault lines where multiple temporalities of change are entangled with normative modes of domination, subordination, and disavowal, the opportunity for a countertemporality, a time of the dead, opened' (2007: 214). The here and now becomes dislocated as traces thought safely buried or erased re-emerge as revenants. In cities undergoing dramatic social and political change, such as Cape Town, these transgenerational phantoms inhabit particular places and constitute their social realities, particularly where the city and society are 'out of joint in terms of both time and space' (Pile, 2004: 217). ${ }^{2}$

In such zones of transition, (re)discovered objects - remains, remnants, ruins - speak of past lives and presences that live on in the contemporary city, even if they are understood as occupying space-times beyond the realms of the living (Boyer, 1996; Edensor, 2005; Spelman, 2003; Till, 2005). The uncanniness of spectral traces complicates contemporary understandings of time and space, and of the city: linear memorial narratives are upset, habitual paths are littered with stumbling blocks and capital no longer circulates in predictable patterns associated with rent gaps. The taken-forgrantedness of urban space shifts.

If spectral traces throw contemporary mappings of the city into disarray, what might a different mapping of the city look like, one that is sensitive to the past injustices that continue to haunt the postcolonial city? Might there also be archaeologies that treat ground as home and resting place, as thresholds through which the living make contact with those who have gone before, rather than as merely subject matter and property? In other words, are there archaeologies that treat bones as both artefacts and ancestors? And how might we, as memory scholars, represent spectral traces phantoms, histories, remnants, submerged stories and ways of knowing - in a way that is recognizable to all those who inhabit the postcolonial city, while also respecting them as silences and gaps?

Inspired by the activists who created spaces for both the dead and the living to (re)assert their rights to the (post)colonial city, we offer two narrative strategies to represent terrains not visible on Cartesian mappings of urban space. First, we describe Cape Town in terms of a memorial cartography anchored by sites of trauma, struggle and popular memory (see also Till and Jonker, forthcoming). Our commemorative mapping plots the echoes that other pasts and places have with contemporary debates, recognizing that these resonances form an affective network granting thick meaning to an inhabitant's experience of place. The mapping of moments and movements of struggle, trauma and memory across and through time is an open-ended project. Much like Pearson and Shanks's (2001) theatrical-archaeological 'deep mappings', Biggs's (forthcoming) practice of auto/ethnographic writings focused by sound and place, and Rendell's (2008) work on architectural and artistic 'site writing', memorial cartographies offer 'polyvocal alternatives to the limitations of disciplinary orthodoxy in academic writing' (Biggs, forthcoming) to represent place and landscape 'through juxtapositions 
and interpretations of the historical and the contemporary, the political and the poetic, the factual and the fictional, the discursive and the sensual' (Pearson and Shanks, 2001: 64-65). By making unexpected points of connection that highlight the processes that tie together places through time and across space, we hope to encourage new spatial and historical imaginaries of the city, thereby offering 'counter-topographies' (Katz, 2004) that defy hegemonic discourses of globalization and understandings of ground as simply property.

In such a mapping, particular places such as Prestwich can be seen as thresholds through which citizens can access voices, inheritances and resources that provide for them a language of belonging, even as these phantoms speak of structural exclusions from the city. In this way, sites of displacement have the potential to disrupt established zones of social belonging, allowing the excluded to re-imagine how they might inhabit the urban spaces from which they and their ancestors were displaced. What materializes through such a memorial cartography is a politics of (re-)inhabiting the postcolonial city grounded in memory work.

Second, we examine Prestwich Place in terms of its haunted archaeologies. Through contestations over the rights to excavate meaning at Prestwich, not only was ground turned over, but digging itself emerged as a haunted practice. The digs that take place in postcolonial cities are haunted by histories of modern archaeology, anthropology, museumology, planning and even psychoanalysis (Jonker, 2005b; Khanna, 2003). Excavation, collecting, classification, preservation and display are historical and contemporary practices that, in the name of science, encrypt spectral traces that exceed the boundaries of these practices. Those traces are radically heterogeneous (after Abraham and Torok, 1994): they are not easily exorcised through memorial narrative, historical accounts, commercial construction, or other methods by which the living attempt to contain a place to fit their own needs. Haunted archaeologies attempt to provide glimpses of these phantoms, and to follow where they beckon: revenants remind us that there are ethical limits on the claims of science and encourage us to follow alternative lines of enquiry into the past.

At Prestwich, the namelessness of the people buried and the absence of archival history seemed to obstruct the potential to mourn. However, activists, through their persistent digs into the histories of injustice and ongoing denial of those histories, opened up spaces for the dead in the spaces of the living. They created possibilities for disenfranchised residents to claim what had been repressed in the mainstream imaginary of the city as shameful inheritances, even if the outcomes of these claims were not ultimately what they had hoped for. The dig, as a form of memory work, offered not only the promise of mourning, but also the possibility of speaking with, in the name of, and for the dead. Digging became, in this vein, a material and political process through which a wide array of actors created meanings about their relationships to past and future lives, and rallied their own versions of social memory.

As we suggest below, the emergence of human remains and haunted sites may work to interrupt taken-for-granted habits of thinking about citizenship and belonging, habits produced by colonial and apartheid articulations of spatiality and racial identity. The contours of memorial cartographies and the depths of haunted archaeologies 
thus disrupt comfortable and established zones of social belonging, while remaining sensitive to the tensions between the desires and hopes of the living, and the lingering presences and secrets of past lives.

At the same time, we understand memorial cartographies and haunted archaeologies as creative acts that honour those who have gone before; both practices disrupt narratives of the new as separate from the old and acknowledge ways that the spectral and the living attempt to inhabit places in the contemporary postcolonial city. Memorial cartographies and haunted archaeologies encourage us to listen as witnesses (compare Taylor, 1997) to geographies of loss that continue to structure contemporary urbanisms.

\section{A MEMORIAL CARTOGRAPHY OF PRESTWICH PLACE}

Memorial cartographies, as an alternative form of representing the significance of the past in the present, mobilize critical spatial and historical imaginaries and call into question the inevitability of the present (compare Hawthorn, 1991; Kearns, 1998). As Ricoeur explains, the work of re-imagination is a backward looking, memorial gesture arising from the possibility of a 'short-circuit between imagination and memory' (2004: 5). Re-imagination can in this way exceed nostalgia by making a political gesture of creative memory work. The 'power of reinvention and renewal' tied to memorialization is one reason why memory became such a vital element of the anti-apartheid struggle's optimism, and continues to have potency after 1994 (Soudien and Meltzer, 2001: 66). For Cape Town, our memorial cartography articulates a geography of intersecting pasts and presents, inscribed by mappings of movements and moments of displacement and dispossession, all the while remaining sensitive to contemporary insufficiencies of transitional justice and public memory.

Because it is often the dead who play the most vital part in arguments amongst the living, we begin our memorial cartography by mapping those buried at Prestwich. Documentary, archival, oral and archaeological evidence painted a picture of an area that, until the mid-nineteenth century, had been used as formal and informal graveyards of the city's underclass: these included not only slaves, but Khoikhoi, Europeans, Africans, Muslims, free blacks and 'other members of the Cape underclass' (Malan, 2003). The individuals and families buried at Prestwich contributed to the vitality and economy of the colonial city; they built the city using the stones they dug out of nearby quarries (Grunebaum, 2007) and worked as 'artisans, fishermen, sailors, maids, washer-women and their children' (Shepherd, 2007: 7). Others buried there included smallpox victims; convicts, executed criminals and political prisoners; suicide deaths; paupers; free poor; and unidentified victims of shipwrecks (Hart, 2003). The informal burial ground of Prestwich Place was where these lower strata of society buried their dead, the denial of access to the Dutch Reformed Church's formal graveyards a final marker of their lack of citizenship.

The location of Prestwich Place and other burial grounds in the area has become an unwanted inheritance in a postcolonial city obsessed with rapid international development. It remains a material effect of the excessive biopower through which the colonial city 
was legally managed and planned. A colonial politics of the dead inscribed the layout and geographical limits of the city according to a thanatopolitical governance, whereby the bodies of local residents were excluded by and from the law (Agamben, 1998; Foucault, 1985; Jonker, 2005a). The frontier, the first inscription of the law, is a line drawn between citizen and subject, or between inhabitant and alien/native (Jonker, 2005b). The early colonists ventured past these very first frontiers long ago; yet the erstwhile boundaries between self and other continue to haunt the city in unexpected ways. In many cases, these old boundaries are still recalled by the city's street names. Strand Street (Beach Street), for example, recollects where the ocean-bound edge of the city once was; Buitenkant Street (Outer Edge) marks the easternmost boundary of the old city, its intersection with Strand Street guarded by the old military sentinel that is the Castle of Good Hope; and Buitengracht Street (Outer Canal) marks the western boundary of the old city, beyond which once lay the 'menace of wild animals [and] the depredations of marauding Hottentots' (Murray, 1964: 3), those 'alien natives' who once inhabited the Cape (Figure 2).

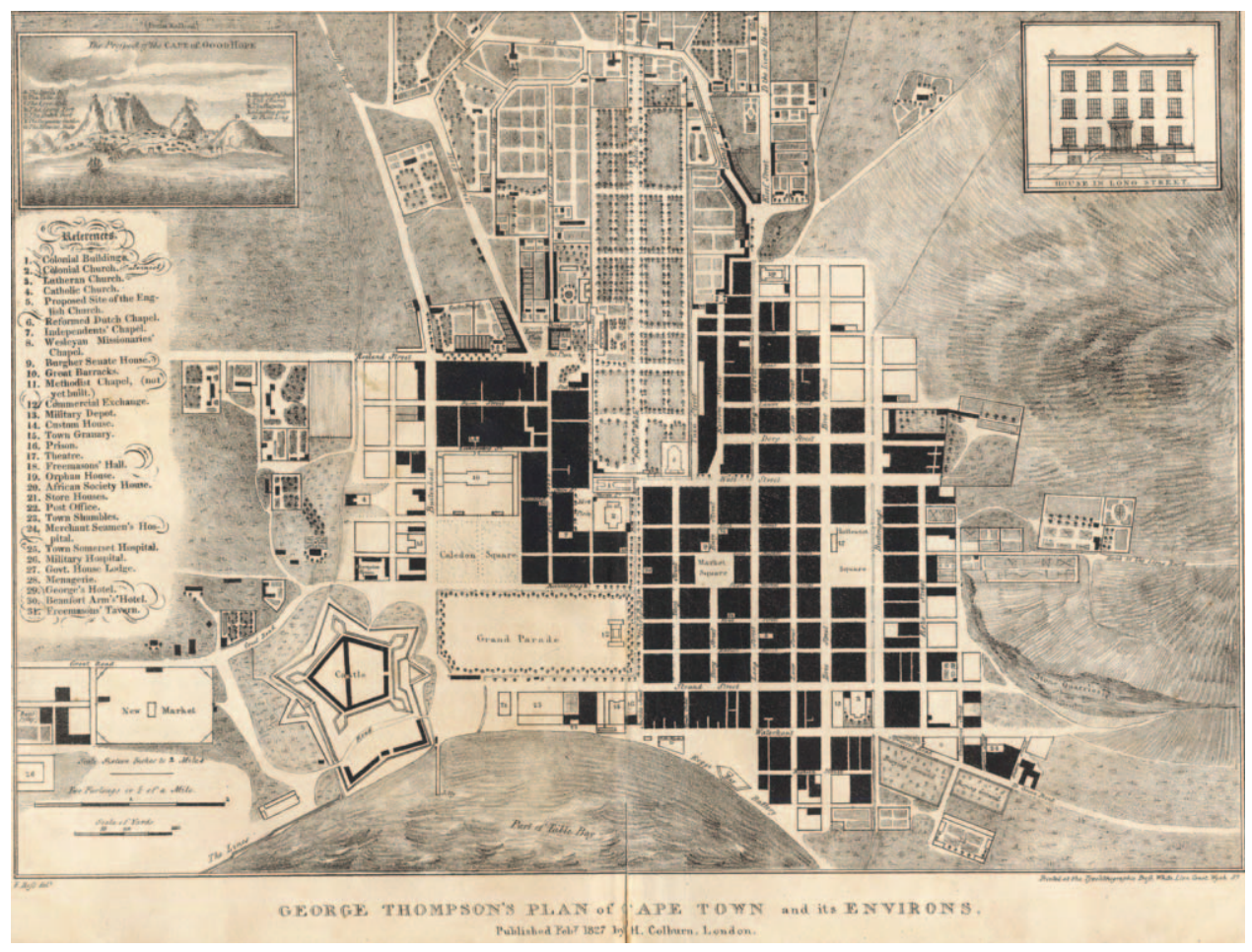

FIGURE 2 Map from: Travels and Adventures in Southern Africa by George Thompson, Esq: Eight Years a Resident at the Cape, Comprising a View of the Present State of the Cape Colony, with Observations on the Progress of British Emigrants (London: Henry Colburn, 1827, 2 vols)

Reprint courtesy of the National Library of South Africa. Prestwich Place is located in the lower right corner of the map, outside of the western border of the colonial city. 
It is from this western end of the city, beyond Buitengracht Street, that Prestwich Place and related burial grounds, including those at Coburn Street, the Paupers' Cemetery, the Malay Cemetery, the South African Missionary Cemetery for Heathens and Slaves, the Ebenezer Howard Cemetery, the Chinese Cemetery and the Tana Baru Cemetery, stretched out in the area that would be later be named District One. The colonial Buitengracht Street boundary would come to prescribe the (dis)location of the informal burials of the city's slaves, freed slaves and poor, excluded from burial grounds within city walls: here, then, is the imprint of a 'bare death' by which colonial sovereignty prescribed the geographical fate of the colonized body, exercising biopolitical power over the material remains of the subject even after life. ${ }^{3}$ Colonial spatial settlement was thus produced in conjunction with the colony's legal authority over the dead, manifested in its regulation of the corpse of the colonial subject.

Of course, the colonial government's exclusionary laws did not go uncontested by residents of the colonial city, and so our memorial cartography also maps other cemeteries in the city, not in terms of thanatopolitical boundaries, but rather as sites of struggle and protest. In the first decade of the 20th century, for example, a still-born child was buried by a Muslim congregation at a cemetery in Claremont that had been closed by the colonial authorities under the Public Health Act of 1883 . The appellants were fined five pounds, which they claimed was 'excessive and vindictive', claiming that Christians had been allowed to bury their dead in a nearby cemetery that remained open. In a 1906 appeal to the Supreme Court of the Cape of Good Hope, the men convicted complained that the motive for the closure of the cemetery was segregation, not the protection of public health ( $R \vee$ Abduroof 190623 SC 451). The appeal was lost. According to the judge: 'Well, that is a matter for the Governor; and I have no doubt that if they can make out a good case, and submit it to the Governor, he will, through his minister, come to their assistance, but when once the Proclamation was issued, it was the duty of these Moslems, as it is the duty of every subject in the country, to obey the law' (at 452).

Another site of struggle was Tana Baru, where 3000 Muslims congregated on 17 January 1886 for a funeral of the child of Amaldien Rhode, a Woodstock fisherman (Weeder, 2008). Tana Baru was a burial ground in the vicinity of Prestwich Place, opened in 1805 by the city for people of Muslim faith in an area previously known as the Chinese Cemetery, above current-day Bo Kaap, on the slopes of Signal Hill. Tana Baru is sacred ground in the city; it is the final resting place for such holy men as Tuan Guru, the founding figure of Islam at the Cape. The funeral procession was held to protest the 1884 legislation that closed these western cemeteries in the wake of a devastating smallpox epidemic. When policemen arrived to take the names of mourners, a riot broke out, and a second burial took place that day (Worden et al., 1998: 210-211).

The strong opposition to cemetery closures by Muslim communities of the colonial city was a response to an imperial order that legitimated expansionary plans for reordering the growing colonial settlement in the name of 'modern science', in spite of the religious beliefs and traditions of those affected. It would be a foreshadowing of how sanitation and illness would become a pretext for the removals and slum 
clearances of neighbourhoods in the desire to build modern cities in the twentieth century, including the first removals of 'Black Africans' from District Six to the outlying Uitvlugt (later known as Ndabeni) through the Public Health Amendment Act of 1897 (Swanson, 1977; Worden et al., 1998: 210-11).

Through this presentiment we move again in our memorial cartography to map zones of struggle and displacement across and through time and space, to connect the historical stories of exclusion and protest in the colonial city with those stories of displacement and protest in the apartheid city. Many of the activists protesting the future exhumation and development at Prestwich Place in 2003, who were themselves forcibly removed by apartheid urban planning and racial segregation to the far reaches of the city, made this connection through their memory work and protest actions. Their ancestral dead spoke to them of (re-)inhabiting the inner city, animating a powerful spatial imaginary by which they, as descendents of colonial subjects, might reassert their rights to the city once again, even if only in the form of some memorial recognition.

Although those who resisted development at Prestwich initially phrased their protest in the discourse of the sanctity of the bones and remains of the dead (Weeder, 2003), it became clear that activism and claims to descendancy were also manifestations of a desire to resurrect the memory of inhabiting this inner city space, even to re-inhabit the city, in accordance with this memory of historical displacement. The South African Communist Party, for example, became interested in the site as a fulcrum for its efforts to make the city rethink the place of the poor and working class in the rapidly developing central business district. This was a particularly appropriate request, when one remembers that those inhabiting District One, the area around Prestwich Street, had also been forcibly removed to the Cape Flats once the district was declared 'Whites Only' under Group Areas legislation in the 1960s. Philip Dexter, then treasurer of the party, went further to inform the press that the unearthed bones at Prestwich Place and others uncovered at the Waterfront 'could become an arena of contestation about reparations' (Khoisan, 2003).

The colonial space-times of Prestwich Place in the new city thus overlap and fold into the apartheid geographies of the modern city, and in particular with the displacements of District Six and the exclusions of its residents from Cape Town. District Six is a precinct on the eastern boundary of the old colonial city, that, like District One, was named with the modern spatial reorganization of Cape Town in the early 20th century (Angelini, 2003; Mabin, 1998: 269-70). Once a vital manifestation of the colonial city's existence as a seaport, this vibrant, multicultural precinct birthed, nursed and inspired many of the Cape's musical, literary and artistic legends as well as much of its radical political discourse. All kinds of people lived, worked and loved there: immigrants from Europe, the Caribbean and the Americas, slaves and freed slaves of Southern African and South East Asian origin ( Bennett et al., 2008; Jeppe and Soudien, 1990; Rassool and Prosalendis, 2001). Recent descriptions of Cape Town that narrate the city's history as a locus of creolization identify District Six as an important place and community attracting processes of cultural contact and exchange (Martin, 1999), and forming novel, hybrid Capetonian identities (Erasmus, 2001b).

District Six is often summoned as an image of the uniqueness and vibrancy of cultural life in Cape Town before the forced removals of the apartheid-legislated Group 
Areas Act of the 1960s, much as Sophiatown evokes the golden age of Johannesburg and its tragic apartheid-enforced end (Mattera, 1987; Modisane, 1963). Anti-apartheid activists of the 1970s, for example, described the district's cultural hybrid community as a manifestation of a pre-apartheid identity of cultural dynamism that was destroyed by legislated racial classifications and attendant cultural stereotypes and supposed biological aggregates. If apartheid's metaphor of apart-ness made of it a primarily spatial ordering, then District Six was 'not of South Africa in its apartheid guise, but a place apart' (Soudien, 2001: 114-15).

For this reason, District Six came to be known as the location of Cape Town's most notorious forced removals, for it clearly did not fit apartheid's vision of urban planning. Between 1966 and 1982, its 60,000 residents were methodically removed to townships on the margins of the metropolis. Their houses were bulldozed to the ground, so that today the only remnants of the once vibrant community are the churches, mosques and synagogues - landmarks that stand painfully alone on the otherwise empty land. After the protracted forced removals had cleared the land of almost all signs of habitation, destroying families and tight community bonds, an activist campaign endeavoured to prevent the government rebuilding a white or even a mixed suburb on the land. For the Hands Off District Six movement, a series of protest actions and community meetings that later evolved into the District Six Museum, the empty land was 'salted earth', fit only for a justice to come that would bring with it the restitution of the land to those who had been removed (Prosalendis et al., 2001). Delport, a District Six Museum founder and trustee, writes that this 'monumental emptiness' became an iconic absence upon which popular remembrance of forced removals became focused (2001: 36-7).

Despite efforts to re-inhabit the space with former residents who suffered through forced removals, as well as their descendants, the district remains largely empty (Figure 3). ${ }^{4}$ The barren landscape of District Six remains an icon of the anti-apartheid struggle and a symbol for many South Africans of the apartheid state's large-scale violence against intimate and domestic lives. This vast empty area is a physical reminder of activists' defiance in the face of injustice, an 'open wound', or disturbing presence, in the city, even after apartheid (Layne and Till, 2005). Open plots, in their emptiness, mourn for remembered loss; the territory is a visible haunting of how apartheid violence and dispossession have shaped Cape Town. Confounding attempts of narrative closure through heritage proposals or spatial containment through urban renewal, the District Six and the District Six Museum speak to locals and visitors alike of the need to keep open the memory of the past in the present and the hopes for a more tolerant society in the future (Layne, 2008).

As if to summon these living ghosts, The Prestwich Place Committee had originally named itself the Hands Off Prestwich Street Ad Hoc Committee; indeed, many Hands Off District Six's members were instrumental in formulating the Prestwich Place campaign. Both the Hands Off District Six and Prestwich Place organizations have been said to arise from what former District Six Museum director Layne (2004) calls 'a crisis of authority, of the right to speak'. This crisis of political representation is also 


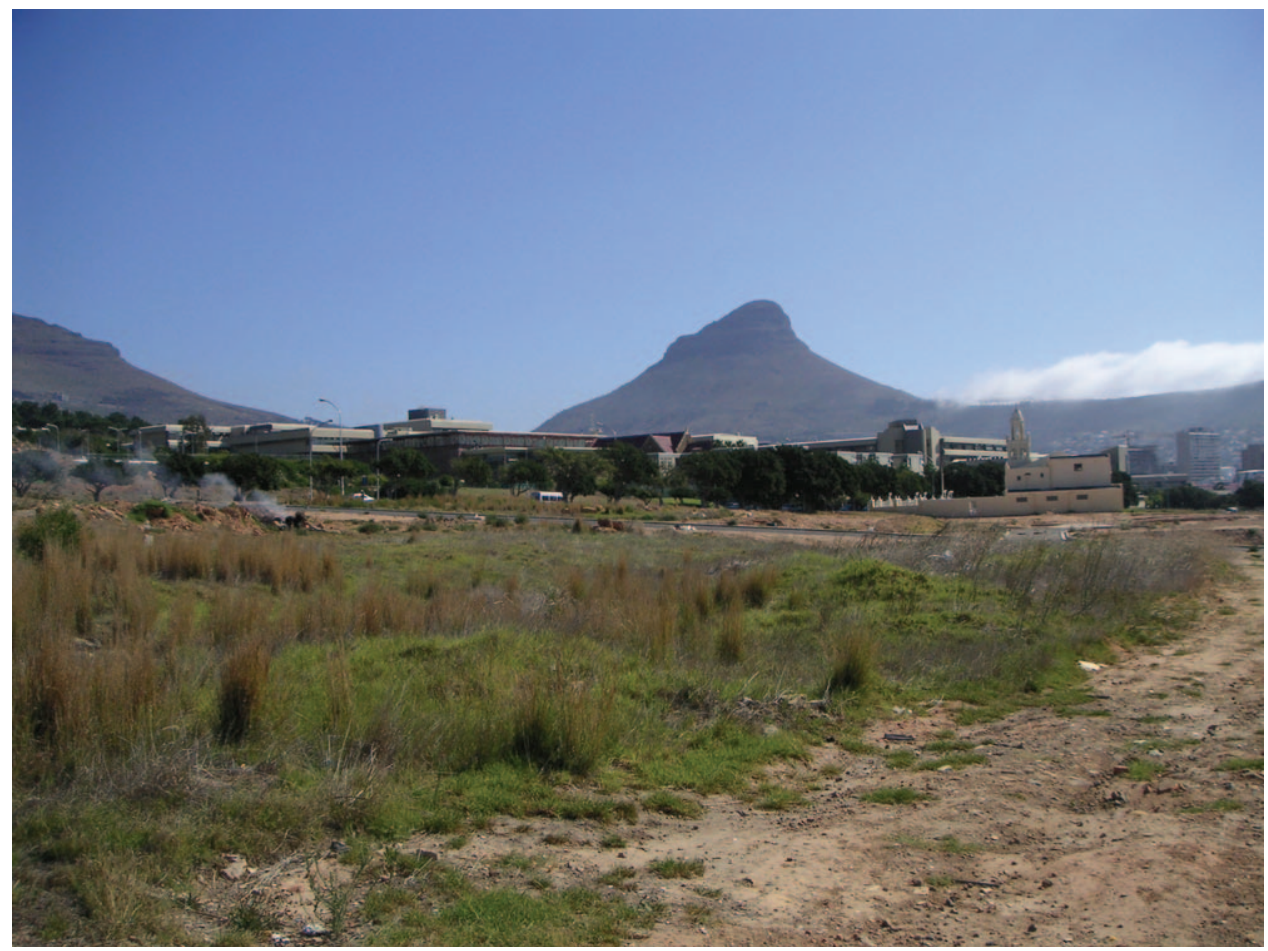

FIGURE 3 The emptiness of District Six

Photograph courtesy of Andrew Tucker, 2007.

the crisis of re-imagination, the necessity of being creative in the work of recognition and identification, particularly when old racial identities continue to crowd out social and political imaginations. As Coombes writes, 'under apartheid what was construed as the problematic conjuncture of working-class origins, cosmopolitan aspirations, and being African or "colored" has left a complicated legacy. This means that the memory of District Six is not easily accommodated in the "new'" South Africa either' (2003: 118).

Both the campaigns for District Six and Prestwich Place battle against fixed and restrictive delineations of identity, and against an amnesia of the future anterior, or what might have been possible, to re-imagine the city (Jonker, 2005b: 35-48). Without condoning the excesses of re-imagination, former residents and activists claim that popular, albeit romanticized, narratives of District Six trump official narratives based upon statistical data or modernist urban planning (see also Field, 2003). According to Soudien and Meltzer, 'it matters not therefore that the details of a story are wrong. What matters is the right to remake' (2001: 66-9).

In our memorial cartography, then, District Six and Prestwich Place inscribe both the historical time-spaces of colonial and capitalist urbanization, their zones of creative destruction, as well as the time-spaces of social memories, their inclusions and exclusions. On one side of the city, District Six reminds us that Cape Town was the locus of the creolization and creative ferment that thrived in the least pretentious areas 
of a busy port. Yet apartheid laws that legislated a tripartite racial identity (of 'white', 'coloured' and 'Black') halted cultural hybridity spatially by physically separating people through forced removals and areal segregation (Field, 2001; Platzky and Walker, 1985; Western, 1981). ${ }^{5}$ On the other side of the city, the gentrified spaces and chic facades that now populate the area around Prestwich Place make little room for remembrance. Indeed, many of the histories of District One, now known as Green Point, are lost to contemporary denial about slave ancestry and archival gaps. Speaking about the silences and spectral traces encrypted in the postcolonial archive, Achille Mbembe warns:

Archiving is a kind of interment, laying something in a coffin, if not to rest, then at least to consign elements of that life which could not be destroyed purely and simply. These elements, removed from time and from life, are assigned to a place and a sepulchre that is perfectly recognisable because it is consecrated: the archives. Assigning them to this place makes it possible to establish an unquestionable authority over them and to tame the violence and cruelty of which the 'remains' are capable, especially when these are abandoned to their own devices. (2002: 22)

Mbembe's words remind of Prestwich Place (Figure 4), and the revenants who emerge, uncalled, from the absences and silences of the state's archives.

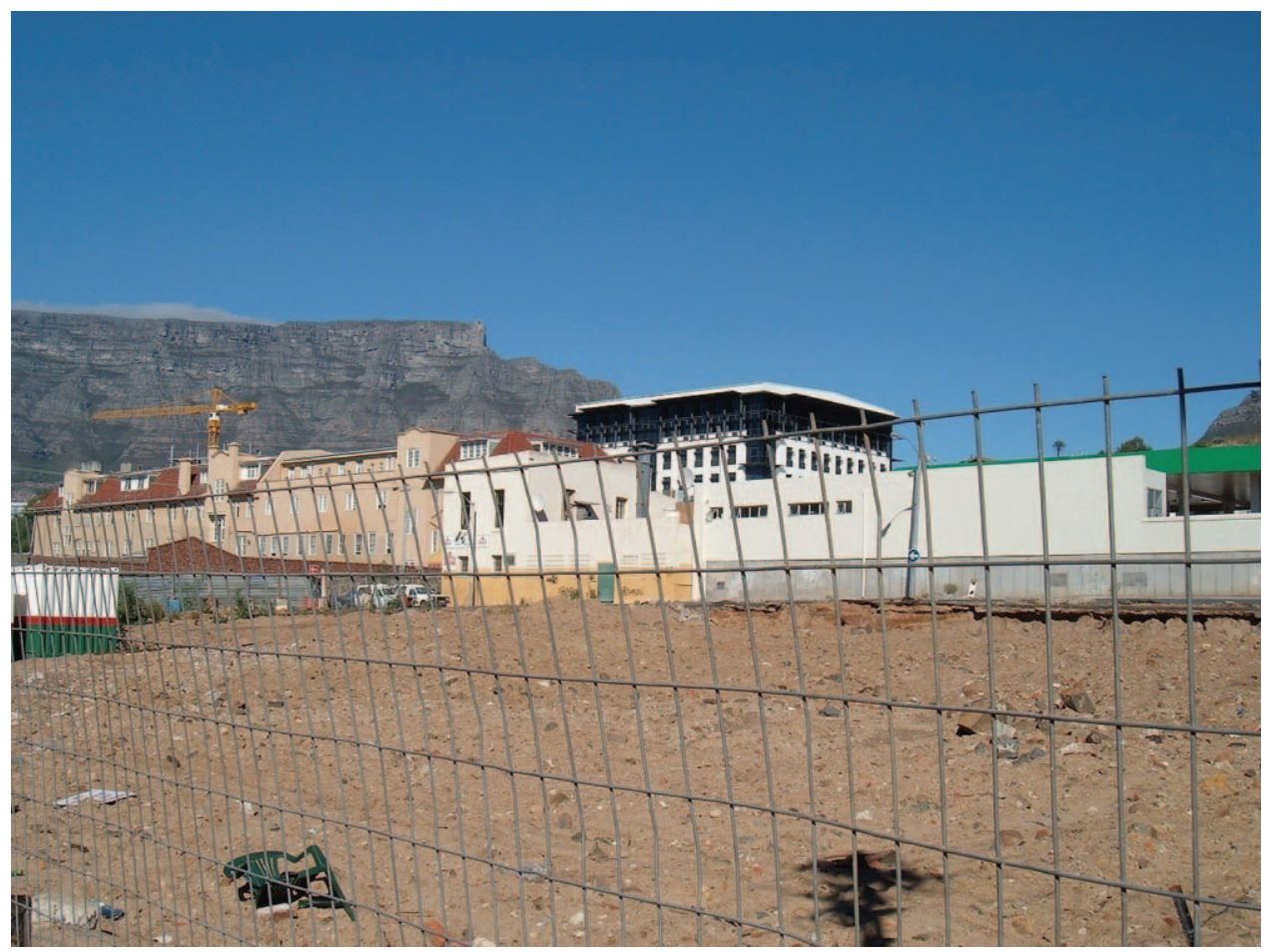

FIGURE 4 Prestwich Place after exhumation

Photograph by J. Jonker, 2006. 
The unruly phantoms of District One and the Cape more generally have begun to create a more expansive, and unwanted, landscape of unnamed burials (Malan, 2003, 2004; Murray, 2003; Weeder, 2008). As the Prestwich controversies unfolded, another dispute had emerged at nearby Tana Baru, parts of which had fallen into the hands of private owners who wished to develop the land. The encroachment of urban gentrification threatened not just burial sites, but also a community's right to inhabit the Bo Kaap, the old slave quarter in which the burials are situated (Reed, 2005). The Muslim Judicial Council issued a fatwa on 8 March 2005 forbidding development of the land, although there had previously been varying opinions issued by Islamic universities (Merten, 2005). Here, as in Prestwich, the emergence of the dead crystallized tensions amongst the living about how space is inhabited. Similar disputes took place on the other side of Table Mountain at Oudekraal, where development was eventually prevented by legal action invoking constitutional protections of cultural heritage (Oudekraal Estates (Pty) Ltd v City of Cape Town and others 20043 All SA 1, also reported as 2004 (6) SA 222 (SCA)). Another controversy that preceded the Prestwich debates, but was still fresh in the public consciousness, was over an area known as 'The Woods'. A development at the foot of Table Mountain on property belonging to a private school was halted when oral histories about the significance of the site as a sacred Muslim burial ground conflicted with an archaeological study that failed to find any burials or remnants of the kramat of Sayed Abdul Malik. Yet customs and oral histories attested to traditional significances of the place to worshippers (Tayob et al., n.d.). At stake was which discourses and practices could lay claim to the geographical significance of a place (but see Jacobs, 1994).

Prestwich Place remains distinctive amongst these spectral sites of transition, however, because of the magnitude of the space implicated, its historical significance, its location in terms of property values, and also the timing of its emergence. Like a premonition, the dead at Prestwich began to speak to the living shortly prior to and during the sometimes violent confrontations over housing, land restitution and reparations amongst displaced communities in Cape Town that took place a mere 10 years after the 1994 transition to democracy. The living, it seems, were ready to listen to the dead at Prestwich and began to make space for the dead in the postcolonial city through public meetings, protest actions, candlelight vigils, marches, community radio shows and occupying public spaces in the city. Within this context, we (re)locate Prestwich Place in our memorial cartography from the intersection of discourses of cultural property and urban planning, to the intersection of public memory and transitional justice.

As Henri and Grunebaum (2004) describe, the claiming of Prestwich Place as an act of memory by activists disrupted the official amnesia of 'nation-building-as-reconciliation'. By this, they refer to how the TRC has underwritten a discourse of reconciliation that discerns 'admissible from inadmissible forms of historical consciousness and representations in the domains of the public'. Similarly, others have described the TRC as a 'paradox ... of history's simultaneous exhumation and burial' (Rassool et al., 2002: 116), words that remind us of the incomplete transition to a more equitable society.

The TRC's establishment was a product of negotiated settlement and, as such, marked by compromise. After the unbanning of the anti-apartheid movement by the 
then ruling National Party in 1990, there followed a period of political turmoil bordering on civil war. Through a series of 'talks', the disputants eventually arrived at a mechanism for addressing the human rights violations of the past and establishing a democratic government. The moral calculus of transition was a simple, if relatively novel, one: retribution would be foregone in exchange for the truth about apartheid's violent history. A public process opening out into catharsis, the narration of grief and, hopefully, remorse and forgiveness would then clear the path to reconciliation.

Yet if the TRC has been unable to achieve enduring reconciliation, it is because, as Mamdani had already pointed out in 1996, its hearings and report narrated apartheid as a history of the few, of perpetrators and individual victims, rather than as a history of the many, of beneficiaries and shared victimhood (see also Mamdani, 2002). The TRC had only investigated a narrow category of 'gross' human rights violations, such as murder and torture, and only heard cases arising after the Sharpeville massacre of 23 September 1960 (but see Fullard and Rousseau, 2008). What has been left out is 'unfinished business' in the words of Bell and Ntsebeza (2001), the violence of the everyday and the continuities of the colonial past (see also Derrida, 2002; Rassool et al., 2002).

As our mapping has indicated, this violence and continuity also remains materially inscribed in the city. With the discovery of human remains at Prestwich Place in 2003, familiar and unfamiliar knowledges of the urban territory became unstable: thousands of early slave burials, seemingly out of place at the construction site of luxury apartments in central Cape Town, revealed an uncanny geography of the post-apartheid city. The (re)discovered burial ground defamiliarized and made inhospitable an area that had been regarded as a safe home for white and foreign capital, well known for its upmarket restaurants, trendy design boutiques and luxury living. Located on the boundary of the old colonial city, where riots and protests against colonial policy took place, Prestwich Place recalled histories of the displacement of non-citizens and of anticolonial struggle all but forgotten until now. The past that came to light at Prestwich was at once familiar - the boundaries of a colonial settlement still present in the street names and layout of the contemporary city - and yet unfamiliar, at least to the extent that this past had been overlooked by postcolonial and post-TRC memorializations of the new South African nation.

Sites such as Prestwich Place and District Six, and the broader emerging cultural landscape of which they are a part, are landmarks of a cartography of incomplete political transformation. Occupying central and prominent spaces in the city, these places recall the haunting presence of the past and as such anchor our memorial cartography of the city. And yet revenants at Prestwich also challenge us to imagine a different practice of excavation and understanding of trace. In the next section, we develop the concept of haunted archaeologies as a politically transgressive practice that unearths the connections between the material remnants of the past, forms of descendancy, genealogies of proprietorship and histories of citizenship. To make trace into testimony and remnant into eyewitness: here is a vision of a humanizing archaeological gesture. 


\section{HAUNTED ARCHAEOLOGIES: DIGGING FOR REMNANTS, TRACES, AND TRAUMA}

As a practice of digging, haunted archaeology is a category that subsumes various embodied responses to the ground of a haunted place. At Prestwich, for example, individuals claimed and denied emergent ancestral spirits through different kinds of digs. After developers excavated the site for construction, professional archaeologists exhumed the bodies in order to study the remains and resting places. Historians excavated archival presences and absences in order to document the place's historical significances; activists and intellectuals engaged in affective and disciplinary archaeologies of the site's role in the urban subconscious. Citizen initiatives were organized; public hearings about the future of the site were attended; billboards erected in public spaces in the city decried the problematic treatment of human remains; and ultimately city officials and heritage authorities conceded to work with community experts in turning ground in order to create a memorial.

Our haunted archaeology of Prestwich Place unfolds the network of histories, meanings and transgenerational phantoms that cluster around this particular set of digs at this particular place: it excavates the accretion of layers of meaning to the complex ground that has been plotted by our memorial cartography. It is a generous, meaning-endowing gesture that listens to this constellation of places and histories and meanings, even when the subjects that have left those traces are no longer on speaking terms with the living. A haunted archaeology traverses the difficult ground between the anthropometric ${ }^{6}$ dig practised by professional archaeology and the psychic dig inspired by Freud and Foucault, to perceive bones as both object and subject, artefact and ancestor.

Unearthing haunted archaeologies is also an attempt to hear traces as testimony rather than symptom. Ricouer (2004: 174) argues that when subjects can no longer bear witness, one is left only with clues: death brings testimony to an end and abandons its traces as if they were mere symptoms of past subjectivity (but see Agamben, 1999). 'Symptomatic reading', or the reading of clues, as described by Carlo Ginzburg (1989), is an age-old tradition that goes back to the earliest practices of tracking and divination. Common to these readings is 'an attitude oriented towards the analysis of specific cases which could be reconstructed only through traces, symptoms, and clues' (Ginzburg, 1989: 104). Archaeological practice in many countries situates discovered traces within layered, chronologically ordered and site-specific settings, reading these objects as clues for the reconstruction of possible pasts. For anthropometric disciplines such as the archaeology of human remains, remnants of the subject become unresponsive objects left by a desubjectified subject. This kind of archaeology treats the trace not as testimony, but as symptom (Jonker, 2005b).

Despite that many professionals treated the human remains, as a special category of the trace, with dignity, their archaeological practices caused deep offence to many who felt affinity with the burial site (see Grunebaum, 2007). This outrage about archaeological practice at Prestwich Place typically stemmed from perceptions that human 
remains were treated either as archaeological trophies or as mere scientific material. The anxiety about a profession that engages with human remains as symptomatic, rather than as potently bearing witness, pointed to a need for urgent dialogue about the practices, purposes and public life of archaeology, especially in the light of an emerging critical historiography of that discipline in post-apartheid South Africa (Legassick and Rassool, 2000; Ritchie, 1990; Shepherd, 2002a, 2003).

While excavation in most countries is considered a scientific activity and defined by the professional fields of archaeology, anthropology and forensics, in recent years activists have begun to protest the right of these experts to unearth, study and classify human remains at mass graves and burial sites. This sentiment is not new; it is echoed around the world, particularly through struggles of indigenous peoples attempting to claim back skeletons and human remains that have been kept in colonial museums and university collections (Barkan and Bush, 2002; Fforde, et al., 2002; Mihesuah, 2000; Thomas, 2000). The global contestation of the proprietorship of human remains and the right to exercise scientific practices upon them is now reflected not only in political action and rhetoric, but increasingly in legal and policy developments (ICOM, 2004; Native American Graves Protection and Repatriation Act 25 (1990); Vermillion Accord on Human Remains, 1989; World Archaeological Congress First Code of Ethics, 1991). In South Africa, calls for the repatriation of skeletons by indigenous communities are a result of a systematic history of museological and scientific acquisition of human skeletons, in particular of Khoikoi and San peoples who are believed to have originated within the Western Cape (Engelbrecht, 2002; Legassick and Rassool, 2000; Pietersen, 1997).

The formal protests organized by the Prestwich Place Committee opposed not only developers who wished to excavate the site for the purposes of exhumation and development, but also archaeologists and anthropologists who wished to excavate the site for the purposes of anthropometric study. At the very first public consultation, citizens articulated similar concerns; one person, for example, stormed out shouting: 'Stop robbing graves! Stop robbing graves!' (Shepherd, 2007: 8). The legal interpretations of the newly enacted National Heritage Resources Act seemed to provide for no resolution other than exhumation of the remains. These scientific and legal claims to dig reminded activists of the ways in which another set of their ancestors had been historically objectified.

The haunted archaeologies of Prestwich Place, then, are related to the colonial thanatopolitics we mapped in our memorial cartography. The dignity of (some) human life was rendered irrelevant in the face of an Enlightenment-inspired project of conducting scientific research on 'dying races'. With the unearthing of human remains at Prestwich Place, this colonial past of archaeology and its international trade of human remains resurfaced. The subsequent debates traced a postcolonial geography of displacements, scientific digs, and encounters between the law and the dead (Jonker, 2005b). Fully understanding the significance of Prestwich, therefore, requires a Foucauldian archaeology of archaeology (Foucault, 1982), an unearthing of types of excavations, absences and losses, longings and desires, and ways in which transgenerational phantoms speak to the living. 
As Legassick and Rassool explain, after military subjugation, the Khoisan 'were opened to the scientific gaze of the all-powerful coloniser'; their bodies became 'the centre of the transformation of the museum in South Africa as an institution of order, knowledge and classification' (2000: 1-2). ${ }^{7}$ Legassick and Rassool document the extent of a competitive trade between grave robbers and South African and European museums in the early 20th century, and in so doing forcefully make a case for a critical examination of what bone collections now exist in post-apartheid South African museums. As they describe, racial anthropometric study began its decline in the northern hemisphere, in the first decade of the 20th century, following Franz Boas's loss of confidence in its importance. Yet at the same time, this practice of relating the measurements of human anatomical features to racial characteristics became a motivating force of acquisitions for South African museums.

The desire for so-called 'Bushman' remains, considered relics of a dying race by colonial collectors, became steadily more unsavory, and the living and the dead were not well differentiated in the haste to acquire bodies as natural history specimens. One missionary, for example, Reverend $\mathrm{H}$. Kling, was in the practice of sending Bushman skeletons to South African Museum director Louis Péringuey. It appeared that the remains were of recently deceased people with whom Kling had been acquainted, since he was able to clearly identify the individuals (Legassick and Rassool, 2000: 7; Morris, 1987b: 159). Even more notorious was the reputation of Viennese anthropologist Dr Rudolph Pöch, whose programme of racial classification identified Bushmen as one of the remaining 'pure' human races (Legassick and Rassool, 2000: 11; Gordon, 1998: 38). The legacy of his research, for Legassick and Rassool, is 'one of systematic grave robbery, and of clandestine deals for newly dead corpses in the name of science' (2000: 12). An employee of Dr Pöch, a 'Dr.' Mehnarto, was known to cook recently dead bodies to obtain their skeletons (Legassick and Rassool, 2000: 15). Old Katje, the wife of one of the people exhumed and boiled by Mehnarto, was alive to witness it:

After I heard that the white men had taken my relatives' bodies and cooked the flesh off their bones, I prepared to leave for Langberg to report the matter to the Police, but I was told that Bushmen were outside the Law, and that I would get no hearing. People at Kuie told me this, I thought they were right and kept quiet. Since I heard that my relatives' bodies were taken and cooked I am sick from sorrow and I will not recover from the shock for a long time. I wept for days. (quoted in Legassick and Rassool, 2000: 23)

Mehnarto, it turns out, was not the only one guilty of boiling bodies to derive specimens of indigenous anatomy (Legassick and Rassool, 2000: 51). In contrast to the reviled activities of Europe's Resurrectionists, who illegally exhumed bodies to make them available to anatomists, those who excavated Khoisan bodies in South Africa would not have regarded themselves in the same light: 'for the occupation was considered to be quite legal as long as it was non-European bodies that were being exploited' (Morris, 1996: 71). South African Museum director Péringuey believed that no permission was required for excavating 'these old relics' (Legassick and Rassool, 2000: 25). 
The Bushman Relics Act of $1911^{8}$ was introduced partly to stem what came to be seen by officials as a 'ghastly business', although it seemed that the Department of Justice was at least equally motivated by the desire to keep valuable 'relics' from unfairly bolstering the work of foreign scientists (Department of Justice memorandum, quoted in Legassick and Rassool, 2000: 1; see also Morris, 1987a, 1996; Metrowich, 1962). Grave robbing did not, in fact, stop with the promulgation of this Act; Péringuey continued to collect skeletons after 1911, claiming an exclusive right through the new Act's prohibition on exports: '[h]is scientific avidity for human remains meant that he continued to create a climate in which the search for and sale of even recent human remains was encouraged' (Legassick and Rassool, 2000: 45). There is evidence that the famed paleontologist Dr Robert Broom, who would later recount his practice of boiling the flesh off human heads, obtained his research material by a relatively slower process in the 1920s: he would inter the bodies of the recently deceased to allow decomposition to occur 'naturally' and retrieved their clean skeletons soon afterward (Legassick and Rassool, 2000: 51-2; Wells, 1951: 97). As Graham Avery of the South African Museum has argued, '[s]keleton hunting, conducted under the guise of "physical anthropology," continued to devastate large portions of significant Stone Age archaeological sites and was only stopped just prior to the promulgation of the National Monuments Act in 1969' (quoted in Legassick and Rassool, 2000: 82).

These accounts make clear how the disciplines of anthropology and archaeology were complicit with the colonizing project through the production, collection, classification and trade of scientific and cultural knowledge. Following the demise of apartheid in 1994, a number of sites attempted to exorcise the spectres of these colonial configurations of knowledge, power and the indigenous corpse. At the South African Museum, for example, conceptual artist Pippa Skotnes curated an experimental installation entitled: Miscast: negotiating Khoisan history and material culture. Miscast was displayed in 1996, the same year that the TRC hearings were to begin, and provoked strong emotions that had been stoked by past museological practices of collection and display. Miscast collected ethnographic representations of the Khoisan, from the beginning of colonial history to the present, together with the artefacts, plaster casts of human remains and anthropometric instruments of colonial science. While it had been intended as 'a critical and visual exploration of the term "Bushman" and the various relationships that gave rise to it' (Skotnes, 1996: 15) indigenous representatives objected vociferously to what was, in their eyes, simply an offensive and gratuitous exhibition of Khoisan bodies at the South African National Gallery (Abrahams, 1996a, 1996b). The reactions of many critics were no doubt inflamed by memories of the South African Museum's Bushman diorama, an exhibition of plaster casts of indigenous people, naked and frozen in an imagined state of nature (Coombes, 2003: 224ff.; Ritchie, 1990).

While Skotnes's intention to critically exhibit the exhibitors was cause for ceaseless controversy, there was much broader consensus on the question of Sara Baartman's remains. Baartman, a 20-year-old Khoi Khoi woman, was taken from Cape Town to London in 1810, where she became known as the 'Hottentot Venus' and exhibited as a freak and spectacle of exaggerated African sexuality. When she died in 1816, her 
body was dissected and her brains and genitals displayed at the Musée de l'Homme in Paris. Her remains were successfully repatriated and re-interred in 2002, following a dedicated campaign by South African activists and capitulation by the French Senate. Subsequently, the body of Sara Baartman, as well as the narrative of the return of her remains, have been appropriated as symbols of the South African national estate with relevance beyond localized struggle by descendants of the Cape's indigenous peoples (Maseko, 1998, 2003; Pietersen, 1997).

Given these multiple histories that haunt the practice of scientific and anthropological excavation, who may profess to speak for the dead at Prestwich Place? Activists pose this as a rhetorical question denying the claims of scientific expertise to do so: for those tainted by recent histories of grave robbery as scientific research may surely not presume to speak for (or even of) the dead. However, a serious attempt to answer this question must be made if we are to treat bones as ancestors and listen for their testimony: who then speaks as descendant? To answer this question, our haunted archaeology reveals juridical histories that trace the construction of the legal subject who speaks on behalf of the dead.

The National Heritage Resources Act (NHRA) allows only those who can show direct descendancy to have legitimate input into decisions made about ancient graves (Section 36(6)(b) of Act 25 of 1999). While this language of descendancy was an understandable step away from the racial and ethnic classifications of apartheid, the new heritage statute proved to be a significant obstacle to activists mobilizing around Prestwich Place; individuals were unable to show direct descendancy, in part because of familial silences about ancestry caused by shame, lack of record-keeping and the racialization of genealogical narratives. Yet the NHRA, like much other legislation of the past 10 years, is regarded as breaking with its equivalents of the past, which had typically demarcated burial places as archaeological objects to be protected, or, with increasing urgency, as memorials to those fallen in service of the nation (Townsend, 2003: 62; see Bushman-Relics Protection Act 22 of 1911; Natural and Historical Monuments Act 6 of 1923; Natural and Historical Monuments, Relics and Antiques Act 4 of 1934; National Monuments Act 28 of 1969; National Monuments Amendment Act 13 of 1981).

South African law's regard for the burial site can be further traced to the Roman law of religious places, which treated the grave as an anomaly in the commercial life of properties. This exceptionalism based upon religiosity was transformed, in the course of the development of the Roman-Dutch law and promulgation of modern legislation governing burial sites, into an exceptionalism based upon nationalism - thus the law inaugurated nationalism as a new kind of religiosity (Jonker, 2005b: 79-119). The South African nation was also consecrated by that other heritage object, the relic of the indigenous body, whose statutory reification served to place South Africa on the scientific map, while declaring its indigenous past sacred for the purposes of the colonialanthropological historiographical project (Legassick and Rassool, 2000). As already noted, it was because of the competitiveness of the trade in skeletal materials and a sort of protectionism for the South African scientific endeavour, rather than the scientists' grisly practices in relation to Khoisan burial sites and bodies, that the Bushman-Relics 
Protection Act was enacted in 1911. ${ }^{9}$ South African legal histories, related to both the projects of colonialism and nationalism, thus haunt recently established South African heritage legislation. The NHRA, even as it breaks with apartheid and colonial legal pasts, continues to protect burial places in terms of the contemporary project of nationbuilding, with all the oversights and deficits this entails (Jonker, 2005b: 79-119).

At Prestwich Place, while the NHRA summoned the practices of professional archaeology, the legitimacy of the discipline's immediate access to the unnamed dead was questioned by Prestwich Place Committee activists. Such protests proclaim that the very act of groundbreaking is a violent one, as can be the professional archaeologist's gaze and work of naming. Indeed, criticisms of scientific archaeology were also made by archaeologists suspicious of a discipline that 'carries within itself the traces of its own formation as a field of knowledge construction, and as a material practice rooted in specific historical and political contexts' (Shepherd, 2002b).

Addressing these concerns about the life of the anthropometric disciplines in the public sphere thus requires an exegesis of their methods and assumptions, based in turn on an excavation of their historical development and teleology. A true commitment to public deliberation about these sciences also requires an acknowledgment of the affective and semantic resonances that have accreted to these bodies of knowledge and been ignored. The dig of haunted archaeologies becomes at once a Freudian excavation of the repressed memories and a Foucauldian archaeology of the genealogies of urban place. As practice, it gives voice to a different present and presence through the excavation of forgetful histories, keeping wounds open by continually confronting and discovering pasts that unsettle the present, those places where the city is out of joint.

Edward Saïd mentioned the possibility of a re-imagined archaeology as activist excavation in his Freud and the non-European, in which he notes that (anthropometric) archaeology has been used both as a scientistic base for national ideology, and brought into the service of a liberation struggle as evidence of a living indigenous tradition (Saïd, 2003: 45ff.). One archaeological practice uses facts to substantiate identity and rationalize the nation's founding myth, while the other is a practice that challenges archaeology 'so that those "facts" and the practices that gave them a kind of scientific pedigree are opened to the existence of other histories and a multiplicity of voices' (Saïd, 2003: 50). Haunted archaeologies accompany this desire for ground and trace to speak in unspeakable ways.

\section{CONCLUDING COMMENTS}

At Prestwich Place, it was through the process of excavating past violences that residents attempted to keep wounds open in the city, thereby giving the dead a safe place to haunt, and the living a physical and aesthetic form to mourn for the loss of human life. At stake is whether the work of mapping and digging for spectral traces disturbs, dispels or accommodates ghosts. Unlike the boundaries drawn by colonialists, or the ubiquitous signs created by architects of apartheid segregation, or the territorial 
inscriptions of 20th-century urban planners - strategies used to contain subjects in Cartesian grids and chronologies - memorial cartographies signify the unbounded qualities of place and memory by following the movements of, and thereby creating spaces for, spectral traces in the city. Haunted archaeology, as a place-based activist encounter with pasts and presents, offers the possibility of unearthing the foundations of the psychological and material terrains of the present-day.

It is the living that do the work of remembrance, of returning to inhabit places of memory and bearing witness for past atrocities. Inhabiting is that intimate, corporeal gesture that relates place and memory (Bachelard, 1964; Connerton, 1989; Ricouer, 2004: 41-3). We might even imagine that haunting is an excess of inhabiting; a habitual presence that continues even in its absence, without the limit between presence and absence, or that between life and death (Jonker, 2005b). The emergence of burials at Prestwich Place reminded living inhabitants of the historical relationships between the colonial settlement and its subjects, and of how this legacy persists in contemporary notions of (not) inhabiting and (not) belonging. Like Freud's unheimlich, which recognizes familiarity and unfamiliarity as having an unstable but constitutive relationship, the uncanniness of Prestwich Place carried within its strangeness a promise: the possibility of (re)discovering home. ${ }^{10}$

When looking at the built urban landscapes that resulted from these debates, it appears as though this opportunity was compromised. Two physical structures, one of urban renewal and global development, and one of memorialization, solidly occupy two city blocks. The Prestwich Place Committee was unable to stop development at the site of excavation; despite public hearings, protest actions and legal appeals, the South African Heritage Resources Agency (SAHRA) ruled in favour of the city's decision that the developer had purchased the property rights to this plot of land and excavations resumed in September 2003. Today, a posh Soho-esque apartment building stands across from the Prestwich Street School, one of the only buildings that were left standing following the razing of District One in compliance with the Group Areas Act (District Six Museum, 2007). The 'Rockwell' bears no witness to the dead, having neither exterior memorial plaques nor aesthetic tributes to the history of the place (Shepherd and Ernsten, 2007).

After the court ruling, the remains were excavated and stored temporarily until a concept for a place of memory could be agreed upon. Two victories of the activist campaign resulted in the second physical structure. Out of respect for the dead, a formal procession of honour was held in 2004, whereby activists, spiritual leaders and other Capetonians carefully carried their ancestors in boxes draped with the South African flag through the streets of the city to their temporary resting place, claiming their rights to re-imagine the city as their own (Figure 5). As a result of continued activist work, SAHRA announced in 2005 that no anthropometric studies of the bones would be allowed (Shepherd, 2007). Second, and also in 2005, city and heritage authorities agreed to create a partnership with the Prestwich Place Committee and the District Six Museum to develop an urban design concept that would include an ossuary, memorial park and educational centre (District Six Museum, 2007). 


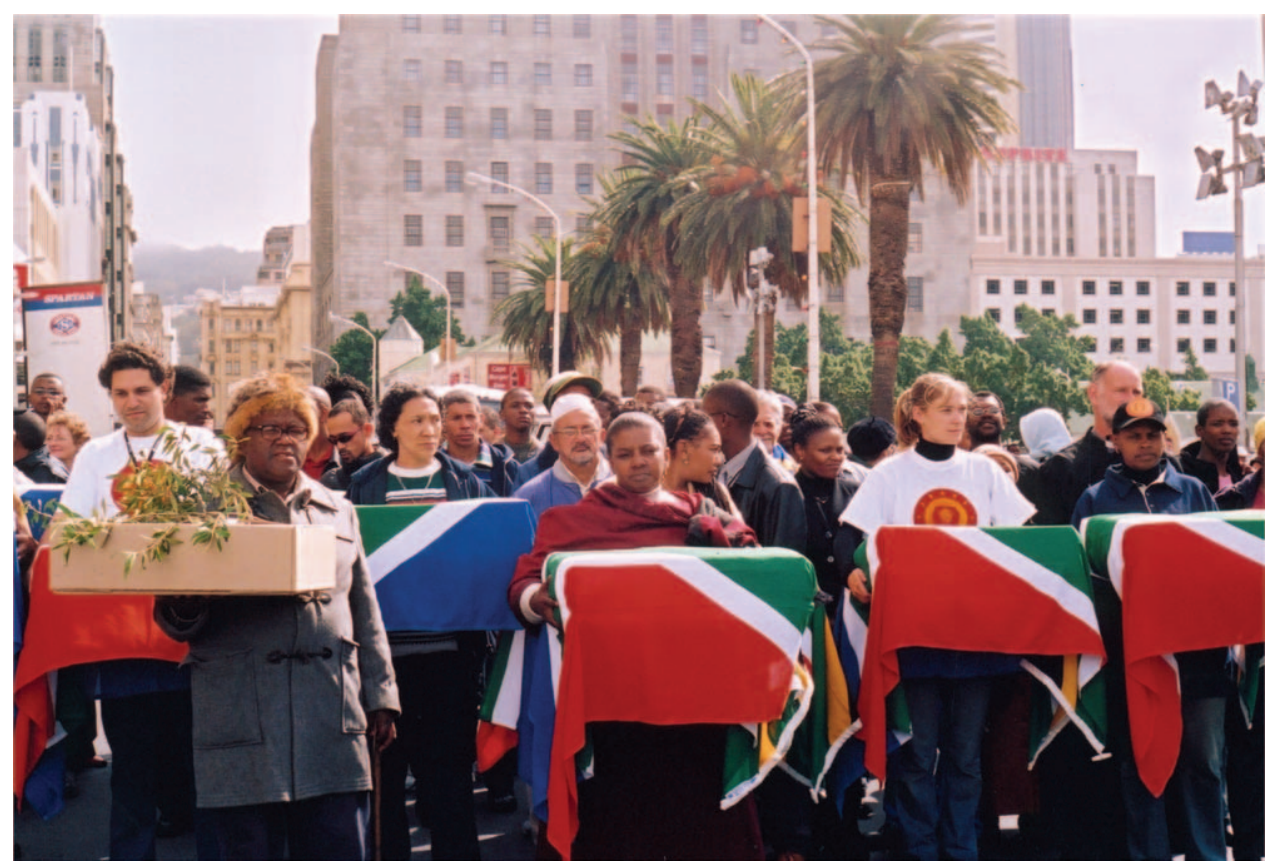

FIGURE 5 Commemorative processional walk from Prestwich Place to temporary resting place, 2004

Image courtesy of the District Six Museum photographic collection.

In April 2008, the Prestwich Memorial (Figure 6) was unveiled, nearby the original excavation site, on ground that belonged to the city and neighbouring the St. Andrews Presbyterian church, which had been sympathetic with descendant concerns (Green Point Community Improvement District, n.d.). The memorial complex includes a brick rectangular building with an interpretative centre on one side, for exhibitions, activities and special events, and an ossuary on the other side, whereby the bones are locked away in an adjoining room, hidden from sight by a thick grille and a plaque announcing their presence. Adjacent to this structure, a memorial garden incorporates historical plaques and remnants of historical city trolley tracks uncovered during the construction of the memorial, and offers the possibility of public events. Somewhat ironically, the new building lies alongside Buitengracht Street, formerly the colonial city's western boundary and now a busy street leading onto one of the city's major highways. ${ }^{11}$

The imposing architecture of the new building nonetheless makes it an anomaly of a public memorial, communicating a sense of enclosure rather than a sense of openness. The exterior of the brick structure is accented by thick, metal security gates that seem to be permanently shut, covering the interpretive centre's doors and partial glass walls with an imposing barrier. Although the building technically is open during office hours, at our most recent research trip in March 2009 we found it necessary to seek permission to ensure that the informal security attendant opened the structure and kept it open 


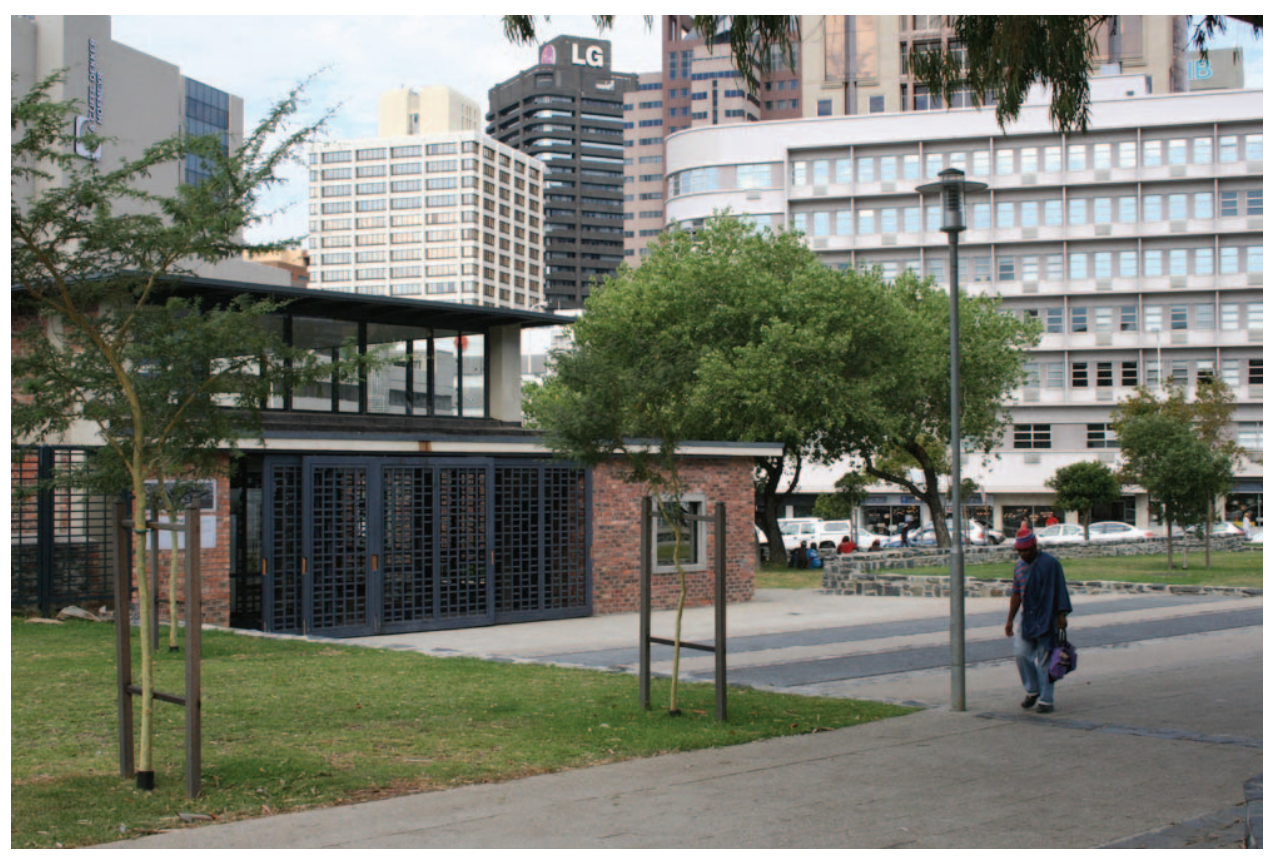

FIGURE 6 The Prestwich Memorial taken from St. Andrews square looking toward Buitengracht Street

Photograph by K. Till, 2009.

long enough for us to read the temporary exhibition inside. (We noted that visitor comments in the guest book were infrequent following the memorial's unveiling.)

Inside, the 16 information panels organized in an 'I-shaped' sequence in the main room made an unsuccessful attempt to find middle ground between the perspectives of groups involved. However, the temporary exhibition was clearly rushed, with repetitions and typographical errors in the text, and no clear conceptual organization. Much of the commentary read as a site museum for Green Point, rather than as a tribute to the people buried at Prestwich Place. We read the current inadequacies of the memorial complex as signs of fracture, as remnants of the bitter disputes that raged between activists, archaeologists, heritage practitioners and city authorities. With its imposing façade and uncertain texts, this building remains haunted by a history that will not be laid to rest yet.

What was lost in the current impasse between differing interests, and as articulated through the built environment of both structures, was the opportunity to more fully and sensitively understand the resonances of this place and its people in the spatial and historical imaginaries of the city. Readings of this urban landscape according to a narrative that pits global capital against local activism are always only partial (Shepherd, 2007; but see Grunebaum, 2007); such interpretations do not recognize the significant mappings and digs that have emerged over the past few years through which the spaces of the city are actively being reclaimed for its inhabitants. 
To date it seems as if the partnership responsible for the memorial complex has not made full use of the District Six Museum's unique expertise. The museum has long engaged different communities in the difficult work of memory, mourning and re-imagining, of listening to the cryptic silences of the hauntings that accompany displacement and trauma. For Bennett and Julius, the museum constantly revisits and interrogates 'theoretical understandings of the nature of memory, particularly traumatic memory, combined with the experience of doing "memory work" as part of its core business' (2008: 62). A critical component of the museum's practice, therefore, is to pay attention to these 'traces of the "forgotten" former communities', such as District One and District Six, through a range of approaches that allow 'the now disconnected diaspora who were once part of its vibrant daily life' to 'reconnect' to their city (Bennett et al., 2008; District Six Museum, 2007: 3-4). Prestwich Place demands this intimate and affective task of naming the nameless dead, of making the archives speak the unspeakable, of connecting the living to past and future lives. Just as at other burial sites that have emerged in Cape Town in recent years, consternation has been caused amongst the living because of the impossibility of identifying the dead, whether materially or through the archive, and the difficulty of consigning them to a safe resting place. Indeed, for Grunebaum, the appearance of bodies 'pried open a time for ... the memory work necessary for social justice': 'as naming, as listing, as re-calling, as re-storying, as accounting, as deferring, as listening, as speaking, and as claiming (2007: 214).

To this end, the District Six Museum, working with the Prestwich Place Committee, began conducting and recording oral histories and site walks of the precinct (what they call 'reminiscence work') with Capetonians who have memories of the area and trace their family histories to District One. Working with local schools, they are also developing educational outreach programs that focus on the history of slavery within the Western Cape. In 2006-07, as part of their regular programming, they coordinated a series of 'The Return: Re-imagining the City' workshops with young learners in the city and surrounding Cape Flats (Sanger, 2008; Soudien, 2008). Shortly before the unveiling of the Prestwich Memorial, they hosted a public education programme to continue the discussions about the future plans for this place of memory. And on 1 December 2008, they coordinated, with the Institute for Justice and Reconciliation and the Prestwich Place Committee, a 75th celebratory parade throughout the city, with poetry reading and celebrations, to commemorate Slavery Emancipation Day (District Six Museum, 2007). As the District Six Museum notes, an important focus of this ongoing work for the Prestwich memory project is to:

understand the many different ways in which people return to places to which they have some sense of connection, even if the return cannot be one which is permanent and residential. This needs to be translated into an active programme through which public space can be mobilized to nurture and develop what it means to belong. (2007: 4)

Mourning and memory work in this way entail the creation of new spatial and historical imaginaries of the postcolonial city. To find peace for such a place as Prestwich, such (re-)imaginative gestures are needed to embrace affective histories and networks 
of meaning, networks that span time and space, and that (re-)inscribe a sense of belonging. It is an intimate, emotional act of discovery that situates these spectral traces, as contemporary residents stumble across, discover or search out these places whether it be as activists, residents, descendants, city officials, heritage and museum experts, forensic scientists, historians, or educators. To listen to bones, to discover remnants and remains, to revisit the archive - these are acts of mourning, of emplacing memory, of making the city and the nation a haunt, and of claiming one's right to inhabit the postcolonial city.

\section{Acknowledgements}

This article is dedicated to the memory of Stan Abrahams. Without the sustained work and generosity of the many activists and heritage workers in Cape Town, including Stan, this research would not have been possible. We also extend our gratitude to Bonita Bennett, Yazir Henri, Heidi Grunebaum, Dr Antonia Malan and Michael Weeder for their thoughtful insights; any errors remain our own. Three anonymous reviewers provided valuable suggestions, as did Gerry Kearns and Andrew Hoskins. The Cultural Sites and Resources Forum and the District Six Museum generously provided us access to their archives. Part of this research was funded by the British Academy, Small Research Grant (40456); the Virginia Polytechnic University International Travel Grant; the Virginia Tech College of Architecture and Urban Affairs, School of Public and International Affairs, and Urban Affairs and Planning. The Department of Private Law, University of Cape Town, and the Department of Geography, University of Minnesota, also provided many resources for this research.

\section{Notes}

1 In June 2003, the South African Heritage Resources Agency (SAHRA) granted the Archaeology Contracts Office, attached to the University of Cape Town and employed by the developer, Ari Efstathiou, a permit for the 'rescue exhumations' of more than 1000 bodies buried at Prestwich Place (District Six Museum, 2007). In 2003, the Cultural Sites and Resources Forum estimated that more than 1500 bodies, mostly infants, were buried at Prestwich. In 2008, the Green Point City Improvement District (n.d.) website cited more than 2500 bodies; Grunebaum (2007) and Weeder (2008) cite close to 3000 bodies.

2 The literature on social memory, hauntings and social justice is too extensive to cite here. Our work draws upon Derrida's (1994) 'hauntology'; Gordon's (1997) understanding of ghosts and social justice; Abraham and Torok's (1994: 165-76) psychoanalytic writings about encryptment and transgenerational phantoms; and De Certeau et al.'s (1998: 133) notion of the 'uncanniness of the "already there"' that defines place.

3 Our notion of bare death inverts Agamben's (1998) concept of 'bare life', while maintaining Foucault's (1985, 1995) ideas of biopower and adopting Mbembe's (2002) understanding of the haunted colonial archive. For an account of the legal management of death and the dead in the colonial settlement and the apartheid city, see Jonker (2005a, 2005b).

4 This is slowly changing as former residents are beginning to move back, in line with the Restitution of Land Rights Act 22 of 1994 and because of the efforts of the District Six Beneficiary Trust, established in 1997. Budget constraints and party politics, however, have delayed this process. 
5 The most prominent laws that underpinned these strategies include the: Native Land Act of 1913; Immorality Act of 1928; Native Trust and Land Act of 1936; Black (Urban Areas) Act 25 of 1945; Prohibition of Mixed Marriages Act No. 55 of 1949; Immorality Amendment Act No. 21 of 1950; Population Registration Act 30 of 1950; Group Areas Act 41 of 1950; Group Areas Act 77 of 1957; Group Areas Act 36 of 1966; Group Areas Development Act 69 of 1955; Community Development Act 3 of 1966; Expropriation Act 63 of 1975.

6 We use anthropometric to refer to disciplines that draw conclusions from the experimental and metric study of human bones.

7 Unless otherwise cited, the following paragraphs draw heavily from this source.

8 Later renamed the Bushman-Relics Protection Act 22 of 1911.

9 The motivations of the Act were evident in its language; it protected aboriginal paintings and sites of archaeological and anthropological interest, including burial grounds and skeletal remains as 'relics'.

10 Freud almost admits to believing in ghosts in his description of the unheimlich (uncanny), an experience of the familiar place becoming unfamiliar or out of place (Freud, 1919: 217). See also Biggs (forthcoming) and Gelder and Jacobs (1989).

11 Construction of the memorial was delayed because of the discovery of more burials beneath the new site: these bones have been laid to rest in the new ossuary alongside the Prestwich Place burials.

\section{References}

Abraham, Nicolas and Maria Torok (1994) The Shell and the Kernel: Renewals of Psychoanalysis, ed. and trans. N.T. Rand. Chicago: University of Chicago Press.

Abrahams, Yvette (1996a) 'Miscast', Southern African Review of Books 43. Available at: http:// web.archive.org/web/20010725193003/www.uni-ulm.de/ rturrell/antho4html/Miscast.html

Abrahams, Yvette (1996b) 'Yvette Abrahams Responds', Southern African Review of Books 43. Available at: http://web.archive.org/web/20010725193003/www.uni-ulm.de/ rturrell/ antho4html/Miscast.html

Adhikhari, Mohamed (2005) Not White Enough, Not Black Enough: Racial Identity in the South African Coloured Community. Athens, OH: Ohio University Press.

Agamben, Giorgio (1998) Homo Sacer: Sovereign Power and Bare Life, trans. D. Heller-Roazen. Stanford, CA: Stanford University Press.

Agamben, Giorgio (1999) Remnants of Auschwitz: The Witness and the Archive, trans. D. Heller-Roazen. New York: Zone Books.

Angelini, Allessandro (2003) 'Spaces of Good Hope: Inscribing Memory, Territory and Urbanity in District Six, Cape Town', Islandla Institute Dark Roast Occasional Paper 13, Islandla Institute, Cape Town. Available at: http://www.isandla.org.za/publications/pubsDRabst.asp\#13 Bachelard, Gaston (1994) The Poetics of Space, trans. M. Jolas. Boston, MA: Beacon Press. Barkan, Elazar and Ronald Bush, eds (2002) Claiming the Stones/Naming the Bones: Cultural Property and the Negotiation of National and Ethnic Identity. Los Angeles, C: Getty Research Institute.

Bell, Terry and Dumisa Buhle Ntsebeza (2001) Unfinished Business: South Africa, Apartheid and Truth. Cape Town: Redworks.

Bender, Barbara (1998) Stonehenge Making Space. Oxford and New York: Berg Publishers. 
Bennett, Bonita and Chrischené Julius (2008) 'Where is District Six? Between Landscape, Site and Museum', in Bonita Bennett, Chrischené Julius and Crain Soudien (eds) City-SiteMuseum: Reviewing Memory Practices at the District Six Museum, pp. , 52-67. Cape Town: District Six Museum.

Bennett, Bonita, Chrischené Julius and Crain Soudien, eds (2008) City-Site-Museum: Reviewing Memory Practices at the District Six Museum. Cape Town: District Six Museum.

Biggs, lain (forthcoming) 'Essaying Place: Landscape, Music, and Memory (after Janet Wolff)', in Catherine Brace and Adeline Johns-Putra (eds) Process: Landscape and Text. Amsterdam and New York: Rodopi.

Boyer, M. Christine (1996) The City of Collective Memory. Cambridge, MA: MIT Press.

Cape Argus (2008) 'Eland Bay Bones may be 500-year-old Khoisan', Cape Argus, 11 February, p. 1.

Cape Times (2003) 'The Issue Is about Us as South Africans', Cape Times, 5 November, p. 14.

Cohn, Bernard (1983) 'Representing Authority in Victorian India', in Eric Hobsbawm and Terence Ranger (eds) The Invention of Tradition, pp. 165-210. Cambridge: Cambridge University Press.

Connerton, Paul (1989) How Societies Remember. Cambridge: Cambridge University Press.

Coombes, Annie (2003) History after Apartheid: Visual Culture and Public Memory in a Democratic South Africa. Durham, NC and London: Duke University Press.

Cultural Sites and Resources Forum (2003) Prestwich Place: Exhumation of Accidentally Discovered Burial Ground in Green Point, Cape Town. Cape Town: Cultural Sites and Resources Forum, University of Cape Town.

De Certeau, Michel, Luce Girard and Pierre Mayol (1998) 'Ghosts in the City', in The Practice of Everyday Life: Volume 2: Living and Cooking, pp. 133-44. Minneapolis, MN: University of Minnesota Press.

Delport, Peggy (2001) 'Signposts for Retrieval: A Visual Framework for Enabling Memory of Place and Time', in Ciraj Rassool and Sandra Prosalendis (eds) Recalling Community in Cape Town: Creating Community in Cape Town, pp. 31-46. Cape Town: District Six Museum Foundation.

Derrida, Jacques (1994) Specters of Marx: The State of the Debt, the Work of Mourning, and the New International, trans. P. Kamuf. New York: Routledge.

Derrida, Jacques (2002) 'Archive fever', in Carolyn Hamilton, Verne Harris, Jane Taylor, Michèle Pickover, Graeme Reid and Razia Saleh (eds) Refiguring the Archive, pp. 38-80 (even numbered pages). Cape Town: David Philip.

District Six Museum (2007) 'Prestwich Research Report: Presented to SAHRA December 2007: Presented by the District Six Museum on behalf of the Project Team, Incorporating the Prestwich Place Project Committee', available from the District Six Museum research archive, Cape Town.

Edensor, Tim (2005) Industrial Ruins: Space, Aesthetics and Materiality. Oxford: Berg.

Engelbrecht, Martin (2002) 'The Connection between Archaeological Treasures and the Khoisan People', in Cressida Fforde, Jane Hubert and Paul Turnbull (eds) The Dead and their Possessions: Repatriations in Principle, Policy and Practice, pp. 243-8. London: Routledge.

Erasmus, Zimitri, ed. (2001a) Coloured by History/Shaped by Place: New Perspectives on Coloured Identities in Cape Town. Cape Town: Kwela.

Erasmus, Zimitri (2001b) 'Re-imagining Coloured Identities in post-Apartheid South Africa', in Zimitri Erasmus (ed.) Coloured by History/Shaped by Place: New Perspectives on Coloured Identities in Cape Town, pp. 13-28. Cape Town: Kwela.

Field, Sean (2001) 'Fragile Identities: Memory, Emotion and Coloured Residents of Windermere', in Zimitri Erasmus (ed.) Coloured by History/Shaped by Place: New Perspectives on Coloured Identities in Cape Town, pp. 97-113. Cape Town: Kwela. 
Field, Sean, ed. (2003) Lost Communities, Living Memories: Remembering Forced Removals in Cape Town. Cape Town: David Philip.

Fforde, Cressida, Jane Hubert and Paul Turnbull, eds (2002) The Dead and their Possessions: Repatriations in Principle, Policy and Practice. London: Routledge.

Foucault, Michel (1982) The Archaeology of Knowledge and the Discourse of Language. New York: Pantheon.

Foucault, Michel (1985) History of Sexuality. Volume 1, trans. R. Hurley. New York: Vantage Books.

Foucault, Michel (1995) Discipline and Punish: The Birth of the Prison, trans. A. Sheridan. New York: Vintage.

Freud, Sigmund (1919) 'The Uncanny', in The Standard Edition of the Complete Psychological Works of Sigmund Freud, Vol. 17, ed. and trans. J. Strachey, pp. 219-52. London: Hogarth Press and the Institute of Psychoanalysis.

Fullard, Madeleine and Nicky Rousseau (2008) 'Uncertain Borders: The TRC and the (Un)Making of Public Myths', Kronos: South African Histories 34: 215-39.

Gelder, Ken and Jane Jacobs (1998) Uncanny Australia: Sacredness and Identity in a Postcolonial Nation. Melbourne: Melbourne University Press.

Ginzburg, Carlo (1989) Clues, Myths, and the Historical Method, trans. J. Tedeschi and A.C. Tedeschi. Baltimore, MD: John Hopkins University Press.

Gordon, Avery (1997) Ghostly Matters. Minneapolis, MN: University of Minnesota Press.

Gordon, Robert (1998) 'The Rise of the Bushman Penis: Germans, Genitalia and Genocide', African Studies 57(1): 27-54.

Gosling, Melanie (2003) 'Council Says Developers Must Appoint Archaeologists', Cape Times, 30 October, p. 3.

Green Point City Improvement District (n.d.) 'Prestwich Remains Blessed and Laid to Rest at Prestwich Memorial in Green Point', press release. Available at: http://www.oranjekloof. co.za/home.asp?m=8\&idkey=737/

Grunebaum, Heidi (2007) 'Unburying the Dead in the "Mother City": Urban Topographies of Erasure', PMLA 122(1): 210-19.

Hands Off Prestwich Street Ad Hoc Campaign (n.d.) 'A Press Statement on the Prestwich Place Burial Ground. Undated Press Release Distributed at Public Meetings in 2003', available from Prestwich Place Project Committee, Cape Town.

Hart, Tim (2003) Heritage Impact Assessment of West Street and Erf4721 Green Point, Cape Town. Report prepared for Styleprops 120 (Pty) Ltd, December. Cape Town: University of Cape Town, Archaeology Contracts Office.

Hawthorn, G (1991) Plausible Worlds: Possibility and Understanding in History and the Social Sciences. Cambridge: Cambridge University Press.

Henri, Yazir and Heidi Grunebaum (2004) 'Re-historicising Trauma: Reflections on Violence and Memory in Current-day Cape Town', unpublished paper available from the authors, Cape Town.

Huyssen, Andreas (2003) Present Pasts: Urban Palimpsests and the Politics of Memory. Stanford, CA: Stanford University Press.

ICOM (2004) ICOM Code of Ethics for Museums. Available at: http://icom.museum/ethics.html/ Jacobs, Jane (1994) 'Earth Honouring: Western Desires and Indigenous Knowledges', in Gillian Rose and Allison Blunt (eds) Writing Women and Space: Colonial and Postcolonial Geographies, pp. 195-231. New York: Guilford Publications.

Jeppe, Shamil and Crain Soudien, eds (1990) The Struggle for District Six, Past and Present.

Cape Town: Buchu Books. 
Jonker, Julian (2005a) 'Excavating the Legal Subject: The Unnamed Dead of Prestwich Place, Cape Town', Griffith Law Review 14(2): 187-212.

Jonker, Julian (2005b) 'The Silence of the Dead: Ethical and Juridical Significances of the Exhumations at Prestwich Place', M.Phil thesis, University of Cape Town, Cape Town.

Kassiem, Anwar (2003) 'Skeletons May Remain in Green Point "Closet"', Cape Times, 4 September, p. 9.

Katz, Cindy (2004) Growing Up Global: Economic Restructuring and Children's Everyday Lives. Minneapolis, MN: University of Minnesota Press.

Kearns, Gerry (1998) 'The Virtuous Circle of Facts and Values in the New Western History', Annals of the Association of American Geographers 88(3): 377-409.

Khanna, Ranjana (2003) Dark Continents: Psychoanalysis and Colonialism. Durham, NC: Duke University Press.

Khoisan, Zenzile (2003) 'HSRC Supports Campaign on city's burial sites', Cape Argus, 18 November, p. 7.

Layne, Valmont (2004) 'Towards a Politics of the Emerging Community Museum Sector in South Africa', paper presented at the 68th South African Museums Association Conference, 1-3 June, Cape Town.

Layne, Valmont (2008) '"Sounds and Voices, Colours and Landscapes": Aesthetics for a Community Site Museum', in Bonita Bennett, Chrischené Julius and Crain Soudien (eds) City-Site-Museum: Reviewing Memory Practices at the District Six Museum, pp. 76-93. Cape Town: District Six Museum.

Layne, Valmont and Karen E. Till (2005) 'Unfinished Stories and Wounded Cities: Archaeological Approaches to Memory in Berlin and Cape Town', keynote lecture presented at the Hands On District Six: Landscapes of Postcolonial Memorialisation conference, 26 May, Cape Town. Legassick, Martin and Ciraj Rassool (2000) Skeletons in the Cupboard: South African Museums and the Trade in Human Remains, 1907-1917. Cape Town and Kimberley: South African Museum and McGregor Museum.

Mabin, Alan (1998) 'Reconstruction and the Making of Urban Planning in 20th-century South Africa', in Hilton Judin and Vladislavić (eds) Blank_, Section E6. Cape Town: David Philip.

Malan, Antonia (2003) Public Consultation Process 9 June to 18 August 2003. Report prepared for South African Heritage Resources Agency and the Developer. Cape Town: Cultural Sites and Resources Forum, University of Cape Town.

Malan, Antonia (2004) 'Noises Off ...': Claiming a Central Role in Reinterpreting South African Cities', Architecture South Africa (Jan/Feb): 13-15.

Malan, Antonia and Crain Soudien (2002) 'Managing Heritage in District Six, Cape Town: Conflicts Past and Present', in A.J. Schofield, William Gray Johnson and Colleen M. Beck (eds) Matériel Culture: The Archaeology of Twentieth Century Conflict, pp. 249-65. London: Routledge.

Malan, Antonia, Noeleen Murray and Ulrike Rivett (2002) 'Managing Heritage - Mapping "Sacred Sites" in Cape Town: A Collaborative Approach', paper presented at the Southern African Association of Archaeologists Biennial Meeting, 7-10 July, Cape Town.

Mamdani, Mahmoud (1996) 'Reconciliation without Justice', Southern African Review of Books 46(3). Available at: http://web.archive.org/web/20010715032454/www.uni-ulm.de/ rturrell/ antho3html/Mamdani.html

Mamdani, Mahmoud (2002), 'Amnesty or Impunity? A Preliminary Critique of the Report of the Truth and Reconciliation Commission of South Africa (TRC)', Diacritics 32(3-4): 33-59. 
Martin, Denis-Constant (1999) Coon Carnival: New Year in Cape Town: Past to Present. Cape Town: David Philip.

Maseko, Zola, dir. (1998) The Life and Times of Sara Baartman [video]. New York: First Run/ Icarus Films.

Maseko, Zola, dir. (2003) The Return of Sara Baartman [video]. New York: First Run/lcarus Films. Massey, Doreen (2005) For Space. Thousand Oaks: Sage.

Mattera, Dan (1987) Memory is the Weapon. Johannesburg: Ravan Press.

Mbembe, Achille (2002) 'The Power of the Archive and its Limits', in Charles Hamilton, Verne

Harris, J. Taylor, M. Pickover, G. Reid and R. Saleh (eds) Refiguring the Archive, pp. 19-26.

Cape Town: David Philip.

Merten, Marianne (2005) 'Muslim Council Issues Fatwa against Property Development', Mail \& Guardian, 1 July.

Metrowich, Frederick Charles (1962) Scotty Smith: South Africa's Robin Hood. Cape Town:

Books for Africa.

Mihesuah, Devon A. (2000) Repatriation Reader: Who Owns American Indian Remains? Lincoln, NE: University of Nebraska Press.

Modisane, William (1963) Blame Me on History. Johannesburg: AD Donker.

Moodie, Gill (2004) 'Old bones of Contention. Historians Want Development of Slave Graveyard Halted', Sunday Times, 25 January, p. 12.

Morris, Alan (1987a) 'The Reflection of the Collector: San and Khoi Skeletons in Museum

Collections', South African Archaeological Bulletin 12(42): 18-21.

Morris, Alan (1987b) 'Reverend Kling's Skeletons', South African Journal of Ethnology 10(4):

159-62.

Morris, Alan (1996) 'Trophy Skulls, Museums and the San', in Pippa Skotnes (ed.) Miscast:

Negotiating the Presence of the Bushmen, pp. 67-72. Cape Town: University of Cape Town Press.

Murray, Marischal (1964) Under Lion's Head. Cape Town: A.A Balkema.

Murray, Nick (2003) 'On Remembering and Forgetting: Sites of Memory in Post-apartheid Cape

Town', Architecture South Africa (Nov/Dec): 12-15.

Native American Graves Protection and Repatriation Act 25 (1990) USC §§ 3001-13

Nuttall, Sarah and Carli Coetzee, eds (1998) Negotiating the Past: The Making of Memory in

South Africa. Cape Town, Oxford University Press.

Pearson, Mike and Michael Shanks (2001) Theatre/Archaeology. London and New York:

Routledge.

Pietersen, Colette (1997) The Politics and Policies of Repatriating Archaeological Skeletal

Material: A Case Study into South Africa's Indigenous Past, MA thesis, University of Cape Town, Cape Town.

Pile, Steve (2004) 'Ghosts and the City of Hope', in Loretta Lees (ed.) The Emancipatory City? London: Sage, 210-228.

Pile, Steve (2005) Real Cities. London: Sage.

Platzky, Laurine and Cherryl Walker (1985) The Surplus People: Forced Removals in South Africa. Johannesburg: Ravan Press.

Prestwich Place Project Committee (2004) Submission to DAC Tribunal, available from Prestwich Place Project Committee, Cape Town.

Prosalendis, Sandra, Jenny Marot, Crain Soudien and Anwah Nagia (2001) 'Punctuations:

Periodic Impressions of a Museum', in Ciraj Rassool and Sandra Prosalendis (eds) Recalling Community in Cape Town: Creating community in Cape Town, pp. 74-9. Cape Town: District Six Museum Foundation. 
Ralphs, Gerard (2008) 'Green Point, Globalisation and the Remains of the Prestwich Street Dead', Archaeologies 4(2): 344-52.

Rassool, Ciraj and Sandra Prosalendis, eds (2001) Recalling Community in Cape Town: Creating Community in Cape Town. Cape Town: District Six Museum Foundation.

Rassool, Ciraj, Leslie Witz and Gary Minkley (2002) 'Burying and Memorialising the Body of Truth: The TRC and National Heritage', in Wilmont James and Linda Van De Vijver (eds) After the TRC: Reflections on Truth and Reconciliation in South Africa, pp. 115-27. Cape Town: David Philip.

Reed, John (2005) 'Booming Real Estate Prices Cloud the View from the Top', Financial Times 29 July.

Rendell, Jane (2008) Site Writing: Art, Architecture and Criticism. London: I B Tauris.

Ricoeur, Paul (2004) Memory, History, Forgetting, trans. K. Blamey and D. Pellauer. Chicago: University of Chicago Press.

Ritchie, Gabrielle (1990) 'Dig the Herders/Display the Hottentots: The Production and Presentation of Knowledge about the Past', MA thesis, University of Cape Town, Cape Town. Saïd, Edward (2003) Freud and the non-European. London: Verso and Freud Museum London. Sanger, Mandy (2008) 'Education Work in the District Six Museum: Layering in New Voices and Interpretations', in Bonita Bennett, Chrischené Julius and Crain Soudien (eds) City-SiteMuseum: Reviewing Memory Practices at the District Six Museum, pp. 96-109. Cape Town: District Six Museum.

Schein, Rich (1997) 'The Place of Landscape: A Conceptual Framework for an American Scene', Annals of the Association of American Geographers 87(4): 660-80.

Shepherd, Nick (2002a) 'Disciplining Archaeology: The Invention of South African Prehistory, 1923-1953', Kronos 28: 127-38.

Shepherd, Nick (2002b) 'Heading South, Looking North: Why We Need a Post-colonial Archaeology', Archaeological Dialogues 9(2): 74-82.

Shepherd, Nick (2003) 'State of the Discipline: Science, Culture and Identity in South African Archaeology, 1870-2003', Journal of Southern African Studies 29: 823-44.

Shepherd, Nick (2007) 'Archaeology Dreaming: Post-apartheid Urban Imaginaries and the Bones of the Prestwich Street Dead', Journal of Social Archaeology 7(1): 3-28.

Shepherd, Nick and Christian Ernsten (2007) 'Post-apartheid Urban Imaginaries and the Bones of the Prestwich Street Dead', in Noeleen Murray, Nick Shepherd and Martin Hall (eds) Desire Lines: Space, Memory and Identity in the Post-apartheid City, pp. 215-32. London: Routledge.

Skotnes, Pippa (1996) 'Introduction', in Pippa Skotnes (ed.) Miscast: Negotiating the Presence of the Bushmen, pp. 15-18. Cape Town: University of Cape Town Press.

Soudien, Crain (2001) 'District Six and its Uses in the Discussion about Non-racialism', in Zimitri Erasmus (ed.) Coloured by history/shaped by place: new perspectives on coloured identities in Cape Town, pp. 114-30. Cape Town: Kwela.

Soudien, Crain (2008) 'Memory in the Remaking of Cape Town', in Bonita Bennett, Chrischené Julius and Crain Soudien (eds) City-Site-Museum: Reviewing Memory Practices at the District Six Museum, pp.18-31. Cape Town: District Six Museum.

Soudien, Crain and Lalou Meltzer (2001) 'District Six: Representation and Struggle', in Ciraj Rassool and Sandra Prosalendis (eds) Recalling Community in Cape Town: Creating Community in Cape Town, pp. 66-73. Cape Town: District Six Museum Foundation. Spelman, Elizabeth (2003) Repair: The Impulse to Restore in a Fragile World. Boston, MA: Beacon Press. 
Swanson, Maynard (1977) 'The Sanitation Syndrome: Bubonic Plague and Urban Native Policy in the Cape Colony, 1900-1909', Journal of African History 18: 387-410.

Tayob, A., M. Patrick, A. Haggie and A. Rafudeen (n.d.) Unpublished papers, Cultural Sites and Resources Forum, University of Cape Town, Cape Town.

Taylor, Diana (1997) Disappearing Acts: Spectacles of Gender and Nationalism in Argentina's 'Dirty War'. Durham, NC and London: Duke University Press.

Thiel, Gustav (2004) 'Green Point Pips Clifton for House Price Rises', Cape Times, 29 March, p. 4.

Thomas, David Hurst (2000) Skull Wars: Kennewick Man, Archaeology, and the Battle for Native American Identity. New York: Basic Books.

Thompson, George (1827) Travels and Adventures in Southern Africa by George Thompson, Esq: Eight Years a Resident at the Cape, Comprising a View of the Present State of the Cape Colony, with Observations on the Progress of British Emigrants, 2 vols. London: Henry Colburn.

Till, Karen E. (2005) The New Berlin: Memory, Politics, Place. Minneapolis, MN: University of Minnesota Press.

Till, Karen E. and Julian Jonker (forthcoming) 'Spectral Ground in New Cities: Memorial Cartographies in Cape Town and Berlin', in Uta Staiger, Henriette Steiner and Andrew Webber (eds) Memory Culture and the Contemporary City: Building Sites. Basingstoke and New York: Palgrave Macmillan.

Townsend, Stephen Stewart (2003) 'Development Rights and Conservation Constraints: Urban Conservation-oriented Controls in the City Centre of Cape Town', DPhil thesis, University of Cape Town, Cape Town.

Vasta, S (2003) 'Is History Repeating itself at Prestwich?' Muslim Views, November, p. 31. Vermillion Accord on Human Remains (1989) Available at: http://ehlt.flinders.edu.au/wac/site/ about_ethi.php

Weeder, Michael (2003) 'A Vital Link to our Unknown Past', Cape Times, 5 September, p. 11. Weeder, Michael (2006) 'The Palaces of Memory: A Reconstruction of District One, Cape Town, Before and After the Group Areas Act', unpublished MA thesis, University of the Western Cape, Cape Town.

Weeder, Michael (2008) 'Topographies of the Forgotten: Prestwich and Cape Town's Nineteenth Century Cemeteries', in Bonita Bennett, Chrischené Julius and Crain Soudien (eds) City-SiteMuseum: Reviewing Memory Practices at the District Six Museum, pp. 32-49. Cape Town: District Six Museum.

Wells, L (1951) 'The Broom Collection of Nama Hottentot Skulls in the Edinburgh University Anatomical Museum', South African Journal of Science, 48(3): 97-102.

Western, John (1981) Outcast Cape Town. Cape Town: Human and Rousseau. Worden, Nigel, Elizabeth Van Heyningen and Vivian Bickford-Smith (1998) Cape Town:

The Making of a City. Cape Town: David Philip.

World Archaeological Congress First Code of Ethics (1991) Available at: http://ehlt.flinders.edu. au/wac/site/about_ethi.php

JULIAN JONKER is Lecturer in the Department of Private Law, University of Cape Town, South Africa, where he teaches history and theory of South African law. He received an MPhil from the University of Cape Town for his work on the ethics of memory and of the encounters between law and the dead. Current research interests include the use of metaphor and rhetoric in legal reasoning, the theory 
of intellectual property law, and the role of language and multilingualism in legal education. In 2002-03 he worked as a researcher at the District Six Museum, and he has practised as a sound artist and community arts producer since 2001. Memory and haunting playing a crucial conceptual role in this work, some of which has been exhibited and performed at the Durban Art Gallery, the Cape Town Festival, NewMediaFest2007 and the Vox Novus new music festival. Address: Department of Private Law, University of Cape Town, Wilfred \& Jules Kramer Building, Middle Campus, Private Bag X3, Rondebosch 7701, South Africa. [email: julianjonker@gmail.com]

KAREN E. TILL is Associate Professor in the School of Public and International Affairs at Virginia Polytechnic University, USA. Her geo-ethnographic research explores place-making, personal and social memory, and creative and collaborative research practices in Berlin, Cape Town and Minneapolis. She worked with the District Six Museum in 2005-06 on a series of 'memory methodology workshops' with community and city leaders in Cape Town and the Cape Flats area. Her publications include: The New Berlin: Memory, Politics, Place (University of Minnesota Press, 2005), the co-edited volume Textures of Place: Rethinking Humanist Geographies (University of Minnesota Press, 2001) and numerous book chapters, art exhibition essays and scholarly articles, including in the History Workshop Journal, Social and Cultural Geography, Urban Geography and Environment and Planning D: Society and Space. She is currently working on three projects, Interim Space, Wall Remnants and Wounded Cities. Address: School of Public and International Affairs, 212 Architecture Annex (0113), Virginia Polytechnic Institute and State University, Blacksburg, VA 24061, USA. [email: ktill@vt.edu] 